Article

\title{
Fe-Cu Doped Multiwalled Carbon Nanotubes for Fenton-like Degradation of Paracetamol Under Mild Conditions
}

\author{
Niurka Barrios-Bermúdez ${ }^{1,2}$ (D), Marta González-Avendaño ${ }^{1}$, Isabel Lado-Touriño ${ }^{3}$ (D), \\ Arisbel Cerpa-Naranjo ${ }^{3(D)}$ and María Luisa Rojas-Cervantes ${ }^{1, *(D)}$ \\ 1 Departamento de Química Inorgánica y Química Técnica, Facultad de Ciencias, UNED, \\ Paseo Senda del Rey n 9, 28040 Madrid, Spain; niurka.barrios@universidadeuropea.es (N.B.-B.); \\ martagonzalezavendano@gmail.com (M.G.-A.) \\ 2 Departamento de Ciencias, Escuela de Ingeniería, Arquitectura y Diseño, Universidad Europea de Madrid, \\ c/ Tajo s/n, Villaviciosa de Odón, 28670 Madrid, Spain \\ 3 Departamento de Ingeniería Industrial y Aeroespacial, Escuela de Ingeniería, Arquitectura y Diseño, \\ Universidad Europea de Madrid, c/ Tajo s/n, Villaviciosa de Odón, 28670 Madrid, Spain; \\ misabel.lado@universidadeuropea.es (I.L.-T.); arisbel.cerpa@universidadeuropea.es (A.C.-N.) \\ * Correspondence: mrojas@ccia.uned.es
}

Received: 16 March 2020; Accepted: 13 April 2020; Published: 14 April 2020

\begin{abstract}
A series of carbon nanotubes doped with $\mathrm{Fe}$ and/or $\mathrm{Cu}, \mathrm{Fe}_{100-\mathrm{x}} \mathrm{Cu}_{\mathrm{x}} / \mathrm{CNT}(\mathrm{x}=$ 0, 25, 50, 75 and 100) has been prepared by an easy method of wetness impregnation of commercial multiwalled carbon nanotubes previously oxidized with nitric acid. The wide characterization of the solids by different techniques demonstrates that the incorporation of Fe and $\mathrm{Cu}$ to the CNTs has been successfully produced. $\mathrm{Fe}_{100-x} \mathrm{Cu}_{x} / \mathrm{CNT}$ samples were tested as catalysts in the removal of paracetamol from aqueous solution by a combined process of adsorption and Fenton-like oxidation. Under mild conditions, $25{ }^{\circ} \mathrm{C}$ and natural $\mathrm{pH}$ of solution, i.e., nearly neutral, values of oxidation of paracetamol between $90.2 \%$ and $98.3 \%$ were achieved after $5 \mathrm{~h}$ of reaction in most of cases. Furthermore, with the samples containing higher amounts of copper, i.e., $\mathrm{Cu}_{100} / \mathrm{CNT}$ and $\mathrm{Fe}_{25} \mathrm{Cu}_{75} / \mathrm{CNT}$, only $2 \mathrm{~h}$ were necessary to produce depletion values of $73.2 \%$ and $87.8 \%$, respectively. The influence of $\mathrm{pH}$ and dosage of $\mathrm{H}_{2} \mathrm{O}_{2}$ on the performance has also been studied. A synergic effect between both $\mathrm{Cu}^{+} / \mathrm{Cu}^{2+}$ and $\mathrm{Fe}^{2+} / \mathrm{Fe}^{3+}$ in Fenton-like reaction was observed. These results demonstrate that $\mathrm{Fe}_{100-x} \mathrm{Cu}_{x} / \mathrm{CNT}$ are powerful Fenton-like catalyst for degradation of paracetamol from aqueous solution and they could be extended to the removal of other organic pollutants.
\end{abstract}

Keywords: Fe-Cu doped carbon nanotubes; paracetamol; Fenton-like reaction

\section{Introduction}

Advanced oxidation processes (AOPs) are based on the formation of highly reactive radicals capable to degrade recalcitrant organic wastewater contaminants with high efficiency [1-4]. Among them, heterogeneous processes based on the production of hydroxyl radicals from the decomposition of $\mathrm{H}_{2} \mathrm{O}_{2}$ by the action of catalysts containing the $\mathrm{Fe}^{3+} / \mathrm{Fe}^{2+}$ couple [5-9] or other elements with multiple redox state [10] have been broadly used. They are known as heterogeneous Fenton-like processes and overcome the drawbacks of homogenous counterparts of the limited narrow working $\mathrm{pH}(3-4)$ and the necessity of recovering the leached iron from the wastewater. In this sense heterogeneous catalysts containing active species stabilized on oxides [6,11-13] zeolites [14-16], clays $[15,17,18]$ or carbon materials [19-23] have been widely applied for the degradation of dyes, pesticides, pharmaceuticals 
and so on. Moreover, magnetite-based catalysts are the most used in the heterogeneous Fenton oxidation, being recently revised [8].

The pharmaceutical compounds are products widely employed throughout the world and their presence in water resources is a worrying environmental issue. Paracetamol (acetaminophen) is one of these pharmaceutical products commonly used for humans as mild analgesics and anti-inflammatories, which is present in waste water treatment plant or even in natural waters $[24,25]$, being necessary to develop efficient treatment processes for reducing its presence in aquatic environments.

Among carbon materials, carbon nanotubes (CNTs) are very interesting as catalysts or alternative supports to the conventional ones due to their excellent properties, such as the high mesoporosity and controlled pore size distribution, hollow and layered structures [26,27]. Furthermore, due to the hydrophobic character of their surface, CNTs exhibit more active sites to interact with organic pollutants. In this regard, different articles have reported the use of iron oxides supported over CNTs as heterogeneous Fenton catalysts for the degradation of phenolic compounds [28-31], herbicides [32], antibiotics [33] and dyes [34]. However, to the best of our knowledge, there are no studies of Fenton-like degradation of paracetamol using iron catalysts supported on carbon nanotubes. On the other hand, $\mathrm{Cu}^{2+} / \mathrm{Cu}^{+}$pairs have been proven by other authors [10,35] and by us [13] as efficient catalysts for Fenton-like processes. All above considered, we have thought that the combination of both $\mathrm{Fe}^{3+} / \mathrm{Fe}^{2+}$ and $\mathrm{Cu}^{2+} / \mathrm{Cu}^{+}$pairs together with the good surface properties of carbon nanotubes could lead to a synergic effect in the performance of this kind of processes. Hence, in this work, we report the facile synthesis of $\mathrm{Fe}-\mathrm{Cu} / \mathrm{CNTs}$ samples prepared by wet impregnation and their use as catalysts in the Fenton-like degradation of paracetamol. The influence of different variables such as the $\mathrm{pH}$ of reaction and $\mathrm{H}_{2} \mathrm{O}_{2}$ dosage on the catalytic activity has been investigated. The stability and recyclability of the catalysts, as well as the leaching and mineralization degree have been also studied.

\section{Materials and Methods}

\subsection{Preparation of the Fe-Cu Doped Carbon Nanotubes}

The commercial pristine multiwalled carbon nanotubes were provided by Sigma-Aldrich (Sigma-Aldrich-Merck, Madrid, Spain) (OD $\times$ L 6-9 $\mathrm{mm} \times 5 \mu \mathrm{m}$ and purity $>95 \%$ ). They were previously functionalized by oxidation with nitric acid, according to the procedure described in [36]. The commercial carbon nanotubes used as raw material showed $\mathrm{CoCu}_{2} \mathrm{Sn}$ as impurity. However, it was removed after treatment with nitric acid in [36]. The oxidized carbon nanotubes (CNTO) were crushed and sieved to a $0.05<\mathrm{d}<0.10 \mathrm{~mm}$ particle size, and then they were treated with iron and/or copper acetates by the incipient wetness impregnation method. A solution containing the corresponding mix of acetates in the appropriate concentration to obtain a metal loading of $7 \mathrm{wt} \%$ (with respect to CNTO) was added drop to drop to $0.40 \mathrm{~g}$ of CNTO. The obtained solid was dried at room temperature for $24 \mathrm{~h}$ and at $60{ }^{\circ} \mathrm{C}$ for $16 \mathrm{~h}$ and finally pyrolyzed under nitrogen flow at $400{ }^{\circ} \mathrm{C}$ for $30 \mathrm{~min}$. Five catalysts were prepared, with the nominal composition of $\mathrm{Fe}_{100-x} \mathrm{Cu}_{x} / \mathrm{CNT}$, with $\mathrm{x}=0,25,50,75$ and 100.

\subsection{Characterization of Samples}

The textural properties of samples were determined from the nitrogen adsorption-desorption isotherms at $-196{ }^{\circ} \mathrm{C}$, by using a Micromeritics ASAP 2010 equipment (Micromeritics, Méringac, France). The samples were previously outgassed at $150{ }^{\circ} \mathrm{C}$ for $8 \mathrm{~h}$ until a vacuum set point of $200 \mu \mathrm{m} \mathrm{Hg}$. The surface area and micropore surface were determined by the BET method and $t$-plot method, respectively, and the mesoporosity characteristics of samples were obtained by the BJH method. The morphology of the $\mathrm{Fe}_{1-\mathrm{x}} \mathrm{Cu}_{x} / \mathrm{CNT}$ samples was analyzed by scanning electron microscopy (SEM). Experiments were carried out with a JEOL JSM 6335F microscope (JEOL, Austin, TX, USA) operating at $200 \mathrm{kV}$. Metal dispersion and nature were followed by high-resolution transmission electron microscopy (HRTEM) using an Oxford Instrument, model: X-Max (Oxford Instruments Nanoanalysis \&Asylum Research, High Wycombe, UK) of $80 \mathrm{~mm}^{2}$ and resolution between 0.127 and $5.9 \mathrm{KeV}$ and by X-Ray 
diffraction using a X'Pert Pro Panalytical (Malvern Panalytical, B.V., San Sebastián de los Reyes, Madrid, Spain) diffractometer with $\mathrm{CuK} \alpha$ radiation $(1.5406 \AA)$, operating at $40 \mathrm{kV}$ and $40 \mathrm{~mA}$.

The content of iron and copper of the samples was determined by inductively coupled plasma optical emission spectrometry (ICP-OES) on an ICP-OES PlasmaQuant ${ }^{\circledR}$ PQ 9000 instrument (Analytic Jena, Upland, CA, USA). The metal leaching after reaction procedure was evaluated by measuring the concentration of metal in the final solution, after filtration through $0.45 \mathrm{~mm}$ Durapore membrane syringe filters, by inductively coupled plasma mass spectrometry (ICP-MS) on a Nexion 300D Perkin-Elmer instrument (PerkinElmer INC, Waltham, MA, USA).

\subsection{Catalytic Activity}

The adsorption experiments of paracetamol (PCM) were carried out in a Batch reactor by contacting $10 \mathrm{mg}$ of catalyst with $25 \mathrm{~mL}$ of paracetamol solution $(50 \mathrm{mg} / \mathrm{L}, 0.33 \mathrm{mM})$ under stirring at $700 \mathrm{rpm}$ and $25{ }^{\circ} \mathrm{C}$. The concentration of paracetamol in the solution at selected times was determined by measurements the UV-vis absorption at $243 \mathrm{~nm}$ in a Cary-1-UV-VIS (Varian Analytical instruments, Madrid, Spain) spectrophotometer. The adsorbed amount of PCM $\left(\mathrm{C}_{\mathrm{ads}}\right)$ was calculated as:

$$
\mathrm{C}_{\mathrm{ads}}=\mathrm{C}_{0}-\mathrm{C}_{\mathrm{t}}
$$

where $\mathrm{C}_{0}$ is the initial concentration of PCM and $\mathrm{C}_{\mathrm{t}}$ is the concentration of PCM in solution at each selected time, $t$.

The decomposition curves of $\mathrm{H}_{2} \mathrm{O}_{2}$ in absence of paracetamol were determined by contacting $10 \mathrm{mg}$ of catalyst with $25 \mathrm{~mL}$ of Milli-Q water and $39.3 \mu \mathrm{L}$ of $\mathrm{H}_{2} \mathrm{O}_{2}(30 \%$ Sigma-Aldrich) (Sigma-Aldrich-Merck, Madrid, Spain). Samples were taken periodically and the concentration of $\mathrm{H}_{2} \mathrm{O}_{2}$ was calculated by measuring the absorbance at $405 \mathrm{~nm}$ of the yellow complex formed with titanyl sulphate [37]. The amount of decomposed $\mathrm{H}_{2} \mathrm{O}_{2}\left(\mathrm{C}_{\text {dec }}\right)$ was calculated as:

$$
\mathrm{C}_{\mathrm{dec}}=\mathrm{C}_{\mathrm{t}} / \mathrm{C}_{0}
$$

where $\mathrm{C}_{0}$ is the initial concentration of $\mathrm{H}_{2} \mathrm{O}_{2}$ and $\mathrm{C}_{t}$ is the concentration at each selected time, $t$.

In order to carry out the experiments of paracetamol decomposition by $\mathrm{H}_{2} \mathrm{O}_{2}, 125 \mathrm{~mL}$ of paracetamol solution were contacted with $50 \mathrm{mg}$ of catalyst and after adsorption equilibrium (in $30 \mathrm{~min}$ ) $196 \mu \mathrm{L}$ of $\mathrm{H}_{2} \mathrm{O}_{2}(30 \% ; 13.8 \mathrm{mM})$ were added. The paracetamol concentration was measured by a high-performance liquid phase chromatograph (HPLC) Agilent Technologies 6120 Quadrupole LC/MS (Agilent Technologies Spain, Las Rozas, Madrid, Spain), equipped with BIN pumps and 6120 Quadrupole LC/MS detection. The separation was achieved on a C18 reverse phase column (Zorbaz RP, Agilent, Agilent Technologies Spain, Las Rozas, Madrid, Spain) using an isocratic mobile phase (50/50 mixture of acetonitrile/water) acidified at $\mathrm{pH} 2.0 \mathrm{with}$ formic acid, fed at $0.5 \mathrm{~mL} / \mathrm{min}$. The amount of decomposed paracetamol was calculated according to Equation (2), by replacing concentrations of $\mathrm{H}_{2} \mathrm{O}_{2}$ by $\mathrm{PCM}$ concentrations.

Some experiments of recyclability of catalysts were carried out. After each reaction, the catalysts were filtered off, washed with Milli-Q water and dried at $110{ }^{\circ} \mathrm{C}$ in a vacuum oven for $7 \mathrm{~h}$. Due to the loss of catalyst produced between successive cycles, the amounts of $\mathrm{H}_{2} \mathrm{O}_{2}$ and paracetamol were rescaled according to the amount of catalyst.

The $\mathrm{pH}$ of the solution was measured at the beginning and at the end of the reaction, but it was not controlled during the same. The amount of $\mathrm{H}_{2} \mathrm{O}_{2}$ used was the corresponding to a concentration of $13.8 \mathrm{mM}$, twice the stoichiometric one, according to Equation (3):

$$
\mathrm{C}_{8} \mathrm{H}_{9} \mathrm{NO}_{2}+21 \mathrm{H}_{2} \mathrm{O}_{2} \rightarrow 8 \mathrm{CO}_{2}+\mathrm{HNO}_{3}+25 \mathrm{H}_{2} \mathrm{O}
$$

and it was chosen based on previous results $[13,21,38]$. For a more detailed explanation of the three former procedures see reference [13]. 
The total organic carbon (TOC) was measured using a Shimadzu TOC-V SCH spectrophotometer (Shimadzu Europa GmbH, Duisburg, Germany). TOC was calculated as the difference between the total carbon (TC) and inorganic carbon (IC) in the liquid samples at selected reaction times.

\section{Results and Discussion}

\subsection{Characterization of Samples}

Figure 1 displays the X-Ray diffraction patterns of the catalysts and the crystallite size of the detected phases, calculated by the Debye-Scherrer equation, are given in Table 1 . The graphitic nature of the walls of carbon nanotubes was clearly observed by the diffraction peaks detected in all cases at $2 \theta=26.2$ and $44.4^{\circ}$ (JCPDS-ICDD 01-0750-1621), and it was not significantly altered by the incorporation of metals to the nanotubes. For $\mathrm{Fe}_{100-\mathrm{x}} \mathrm{Cu}_{\mathrm{x}} / \mathrm{CNT}$ samples, with $100 \leq \mathrm{x} \leq 50$, the diffraction peaks of $\mathrm{Fe}_{3} \mathrm{O}_{4}$ (JCPDS-ICDD 01-079-0418) were observed at $2 \theta=30.1,35.4$ and $62.5^{\circ}$.

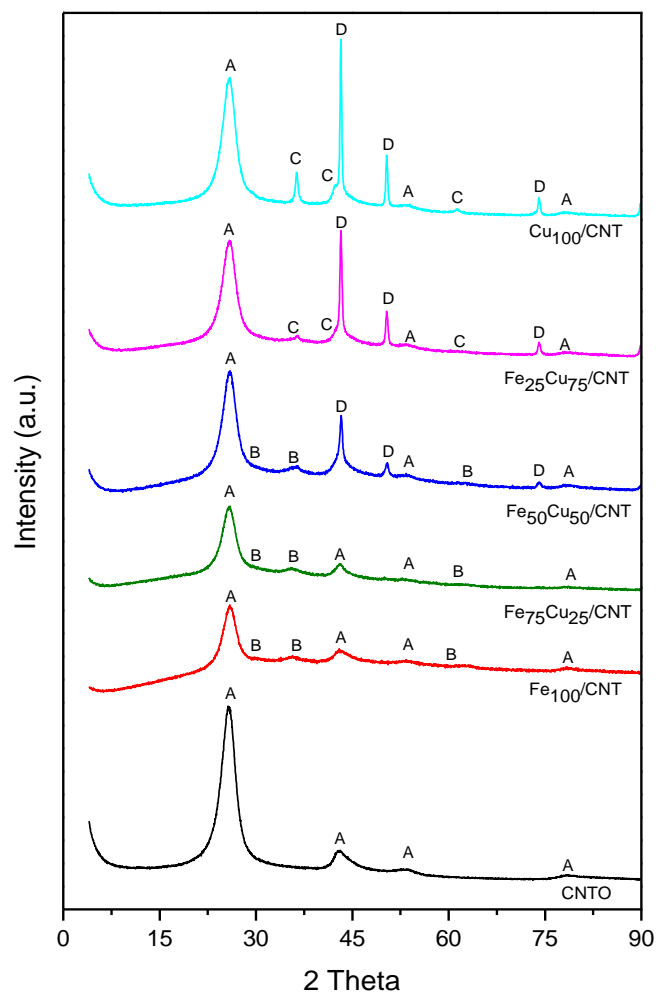

Figure 1. X-ray diffraction patterns of the catalysts. A: graphite; $\mathrm{B}: \mathrm{Fe}_{3} \mathrm{O}_{4} ; \mathrm{C}: \mathrm{Cu}_{2} \mathrm{O} ; \mathrm{D}$ : $\mathrm{Cu}$.

Table 1. Crystallite size $(\mathrm{nm})$ of phases detected in oxidized carbon nanotubes (CNTO) and $\mathrm{Fe}_{100-\mathrm{x}} \mathrm{Cu}_{\mathrm{x}} / \mathrm{CNT}$.

\begin{tabular}{cccc}
\hline Catalyst & $\mathrm{Fe}_{3} \mathbf{O}_{\mathbf{4}}$ & $\mathbf{C u}$ & $\mathrm{Cu}_{\mathbf{2}} \mathbf{O}$ \\
\hline $\mathrm{CNTO}$ & - & - & - \\
$\mathrm{Fe}_{100} / \mathrm{CNT}$ & 2.7 & - & - \\
$\mathrm{Fe}_{75} \mathrm{Cu}_{25} / \mathrm{CNT}$ & 2.9 & - & - \\
$\mathrm{Fe}_{50} \mathrm{Cu}_{50} / \mathrm{CNT}$ & 3.5 & 18.7 & - \\
$\mathrm{Fe}_{25} \mathrm{Cu}_{75} / \mathrm{CNT}$ & - & 24.9 & 15.0 \\
$\mathrm{Cu}_{100} / \mathrm{CNT}$ & - & 29.0 & 20.0 \\
\hline
\end{tabular}

The crystallite size of magnetite increases slightly in the order $\mathrm{Fe}_{100} / \mathrm{CNT}<\mathrm{Fe}_{75} \mathrm{Cu}_{25} / \mathrm{CNT}<$ $\mathrm{Fe}_{50} \mathrm{Cu}_{50} / \mathrm{CNT}$, which seem to indicate that the incorporation of increasing amount of copper diminishes the dispersion of $\mathrm{Fe}_{3} \mathrm{O}_{4}$. When the content of one of the metals was $25 \%$ with respect to the total metal 
load, no crystalline phase of that metal species was observed. Thus, any copper phase was detected in $\mathrm{Fe}_{75} \mathrm{Cu}_{25} / \mathrm{CNT}$ and any iron phase was detected for $\mathrm{Fe}_{25} \mathrm{Cu}_{75} / \mathrm{CNT}$. The diffractograms of catalysts containing copper with $x \geq 50$ displayed the peaks of metallic copper (JCPDS-ICDD01-085-1326) centered at $2 \theta=43.3,50.4$ and 74.1 , probably formed due to the reducing character of graphite sheets. The intensity of the main peak of $\mathrm{Cu}$ increased when increasing the content of copper in the sample, and the crystallite size also did it, from $18.7 \mathrm{~nm}$ for $\mathrm{Fe}_{50} \mathrm{Cu}_{50} / \mathrm{CNT}$ to $29.0 \mathrm{~nm}$ for $\mathrm{Cu}_{100} / \mathrm{CNT}$. Additionally, $\mathrm{Cu}_{2} \mathrm{O}$ (JCPDS- 03-065-3288) was formed in $\mathrm{Fe}_{25} \mathrm{Cu}_{75} / \mathrm{CNT}$ and $\mathrm{Cu}_{100} / \mathrm{CNT}$ samples (peaks centered at $2 \theta=36.5,42.3$ and $61.5^{\circ}$ ), with a crystallite size of 15.0 and $20.0 \mathrm{~nm}$, respectively.

From the values of metal content, determined by ICP-OES (Table 2) it can be seen that the total amount was close to the theoretical ones; however, the copper was incorporated in a higher extent than the iron, and their measured values were anomalously higher than the expected. Unfortunately, we did not have an explanation for this fact, except that of a possible error during the preparation of samples.

Table 2. Content of metal (wt \%) of $\mathrm{Fe}_{(100-\mathrm{x})} \mathrm{Cu}_{\mathrm{x}} / \mathrm{CNT}$ determined by inductively coupled plasma optical emission spectrometry (ICP-OES) *.

\begin{tabular}{cccc}
\hline Catalyst & Fe (wt \% \pm sd) & $\mathbf{C u ~ ( w t ~ \% ~} \pm \mathbf{s d})$ & $\mathbf{( F e}+\mathbf{C u})(\mathbf{w t} \% \pm \mathbf{s d})$ \\
\hline $\mathrm{Fe}_{100} / \mathrm{CNT}$ & $5.87 \pm 0.06(7)$ & - & $5.87 \pm 0.06$ \\
$\mathrm{Fe}_{75} \mathrm{Cu}_{25} / \mathrm{CNT}$ & $4.55 \pm 0.04(5.25)$ & $1.93 \pm 0.01(1.75)$ & $6.48 \pm 0.04$ \\
$\mathrm{Fe}_{50} \mathrm{Cu}_{50} / \mathrm{CNT}$ & $2.91 \pm 0.04(3.5)$ & $3.82 \pm 0.01(3.5)$ & $6.73 \pm 0.04$ \\
$\mathrm{Fe}_{25} \mathrm{Cu}_{75} / \mathrm{CNT}$ & $1.66 \pm 0.01(1.75)$ & $6.51 \pm 0.09(5.25)$ & $8.17 \pm 0.09$ \\
$\mathrm{Cu}_{100} / \mathrm{CNT}$ & - & $8.07 \pm 0.11(7)$ & $8.07 \pm 0.11$ \\
\hline \multicolumn{4}{c}{ * Between brackets: values corresponding to the theoretical ones. }
\end{tabular}

The textural properties of samples are given in Table 3. Samples are mainly mesoporous, as deduced from the comparison of values of $V_{\text {mes }}$ and $V_{p}$ and from the low contribution of $S_{\text {mic }}$ to $S_{\mathrm{BET}}$ values. The oxidation of carbon nanotubes produces an increment of $S_{\mathrm{BET}}$ and pore volume (compare with the values for commercial carbon nanotubes, CNT), mainly of the mesopore volume, because a deagglomeration of nanotubes occurs and a removal of amorphous carbon and impurities from surface is produced. When CNTO are impregnated with the acetates, a decrease in the $\mathrm{S}_{\mathrm{BET}}$ and $\mathrm{V}_{\mathrm{p}}$ is produced, due to the blockage of micro- and mesopores by the metallic phases, which have crystallite sizes in this range. However, a clear trend between the content of metal and the $S_{B E T}$ values is not observed. As deduced from the shape of the isotherms (see Figure S1) and the average mesopore diameter values, the mesoporous structure of carbon nanotubes seems not to be affected by the impregnation with the metallic salts.

Table 3. Textural properties of $\mathrm{CNT}, \mathrm{CNTO}$ and $\mathrm{Fe}_{100-\mathrm{x}} \mathrm{Cu}_{\mathrm{x}} / \mathrm{CNT}$ samples.

\begin{tabular}{cccccc}
\hline Catalyst & $\mathbf{S}_{\text {BET }}\left(\mathbf{m}^{2} / \mathbf{g}\right)$ & $\mathbf{S}_{\text {mic }}\left(\mathbf{m}^{2} / \mathbf{g}\right)$ & $\mathbf{V}_{\mathbf{P}}\left(\mathbf{c m}^{3} / \mathbf{g}\right)$ & $\mathbf{V}_{\text {mes }}\left(\mathbf{c m}^{3} / \mathbf{g}\right)$ & $\mathbf{d}_{\text {mes }}(\mathbf{n m})$ \\
\hline $\mathrm{CNT}$ & 248.0 & 24.7 & 0.799 & 0.518 & 12.9 \\
$\mathrm{CNTO}$ & 329.7 & 24.2 & 1.136 & 0.956 & 13.8 \\
$\mathrm{Fe}_{100} / \mathrm{CNT}$ & 254.6 & 15.4 & 0.817 & 0.707 & 12.8 \\
$\mathrm{Fe}_{75} \mathrm{Cu}_{25} / \mathrm{CNT}$ & 237.8 & 4.8 & 0.775 & 0.674 & 13.0 \\
$\mathrm{Fe}_{50} \mathrm{Cu}_{50} / \mathrm{CNT}$ & 273.6 & - & 0.946 & 0.839 & 13.8 \\
$\mathrm{Fe}_{25} \mathrm{Cu}_{75} / \mathrm{CNT}$ & 323.5 & 0.4 & 1.073 & 0.923 & 13.3 \\
$\mathrm{Cu}_{100} / \mathrm{CNT}$ & 306.3 & 3.3 & 0.969 & 0.865 & 12.7 \\
\hline
\end{tabular}

$\mathrm{S}_{\mathrm{BET}}=$ specific surface area; $\mathrm{S}_{\text {mic }}=$ micropore surface area determined by $t$-plot; $\mathrm{V}_{\mathrm{p}}=$ pore volume at single point at $\mathrm{P} / \mathrm{P}_{0}=0.967 ; \mathrm{V}_{\text {mes }}=$ mesopore volume by BJH between 2 and $50 \mathrm{~nm} ; \mathrm{d}_{\text {mes }}=$ average mesopore diameter $(4 \mathrm{~V} / \mathrm{A})$ by BJH.

The morphology and metal dispersion of samples were studied by SEM and HRTEM. The TEM images of catalysts are shown in Figure 2 . $\mathrm{Fe}_{3} \mathrm{O}_{4}$ nanoparticles of consistent shape were highly dispersed on the nanotubes in the $\mathrm{Fe}_{100} / \mathrm{CNT}$ catalyst (Figure $2 \mathrm{~A}, \mathrm{~B}$ ), with a mean particle size (calculated by 
ImageJ program) of $3.4 \mathrm{~nm}$. These nanoparticles with similar size are also clearly detected in the images of $\mathrm{Fe}_{75} \mathrm{Cu}_{25} / \mathrm{CNT}\left(4 \mathrm{~nm}\right.$ ) and $\mathrm{Fe}_{50} \mathrm{Cu}_{50} / \mathrm{CNT}(4.6 \mathrm{~nm}$ ) samples (Figure $2 \mathrm{C}-\mathrm{F}$ ). The particle sizes observed for $\mathrm{Fe}_{3} \mathrm{O}_{4}$ were very close to those detected by the Scherrer equation (Table 1) and similarly increased slightly in the order $\mathrm{Fe}_{100} / \mathrm{CNT}<\mathrm{Fe}_{75} \mathrm{Cu}_{25} / \mathrm{CNT}<\mathrm{Fe}_{50} \mathrm{Cu}_{50} / \mathrm{CNT}$. However, in the catalysts containing higher amount of copper, i.e., $\mathrm{Fe}_{25} \mathrm{Cu}_{75} / \mathrm{CNT}$ and $\mathrm{Cu}_{100} / \mathrm{CNT}$, these smaller particles associated to $\mathrm{Fe}_{3} \mathrm{O}_{4}$ were not observed. For these two catalysts, a combination of very small particles of copper phases (marked with red circles in Figure 2H,I), highly dispersed and hardly detected, together with big particles of aggregates of copper with size around 50-55 nm (also marked with red circles in Figure 2G,I) seems to exist, which indicates a heterogeneous dispersion of particles in these two samples. The incorporation of the metallic phases to the matrix of carbon nanotubes was also corroborated by analyzing the corresponding EDX spectra of TEM images and the EDX spectra of SEM images of the catalysts (Figures S2 and S3, respectively), although the wt \% of metal measured was lower than the theoretical one, with the exception of $\mathrm{Fe}_{100} / \mathrm{CNT}$ and $\mathrm{Fe}_{75} \mathrm{Cu}_{25} / \mathrm{CNT}$ samples, for which it was close to the $7 \mathrm{wt} \%$. The presence of both elements, Fe and $\mathrm{Cu}$, was observed in the EDX spectra of TEM and SEM images (Figures S2 and S3, respectively) of the mixed samples and only one of the elements, $\mathrm{Fe}$ or $\mathrm{Cu}$, in the corresponding spectra of monometallic samples. However, in order to know if nanoparticles detected in the spectra of mixed samples are nanocomposites of $\mathrm{Fe}-\mathrm{Cu}$, an additional study should be required.

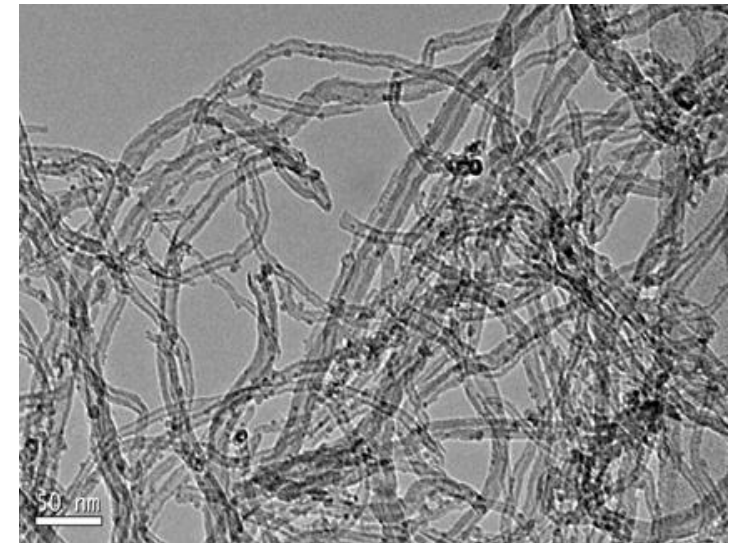

(A)

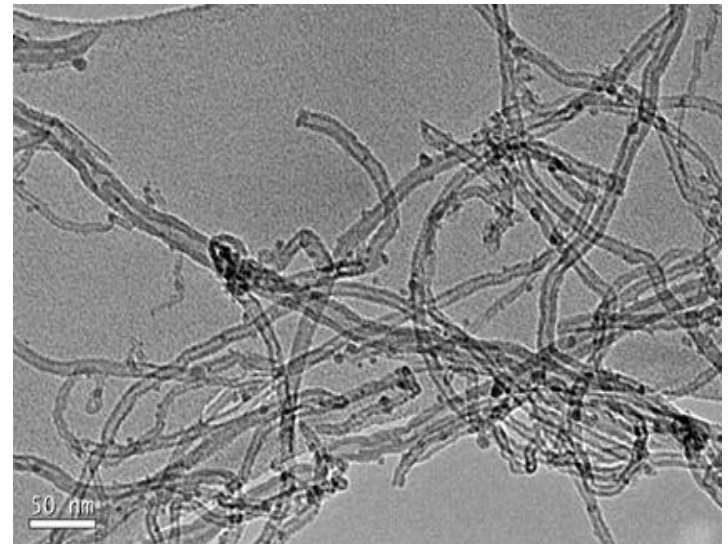

(C)

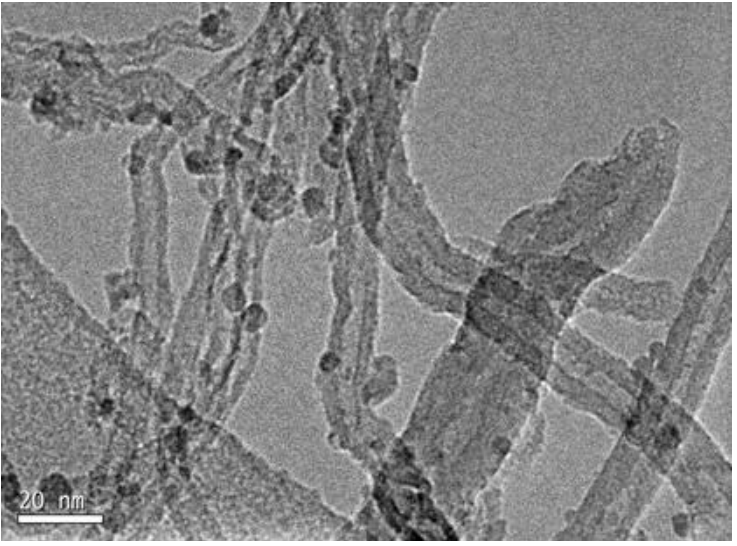

(B)

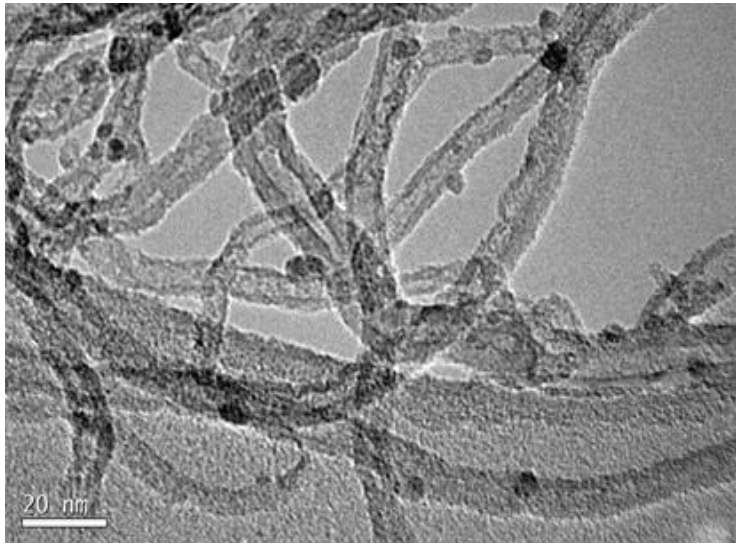

(D)

Figure 2. Cont. 


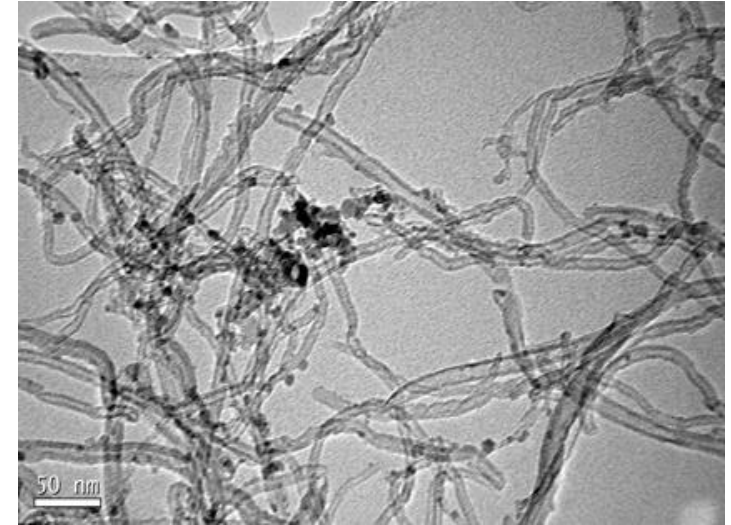

(E)

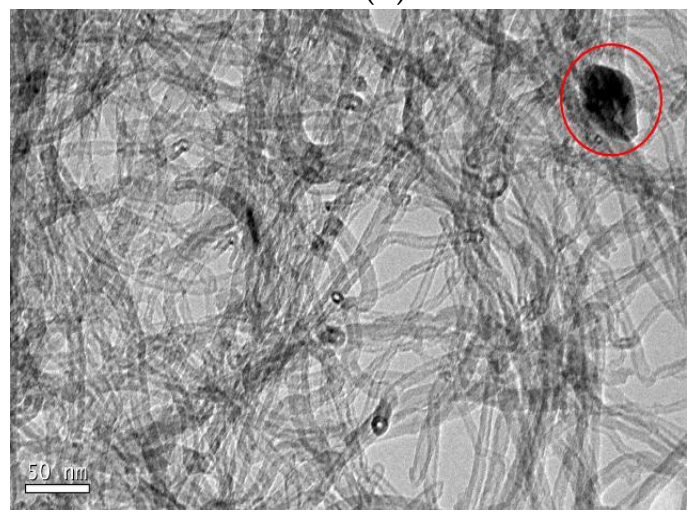

(G)

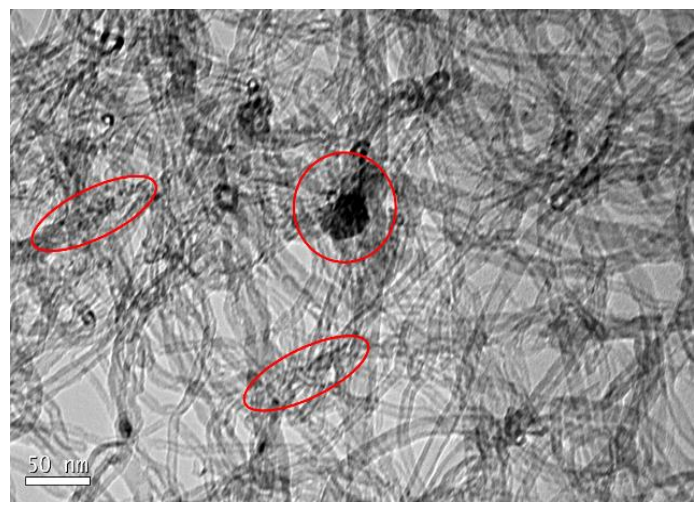

(I)

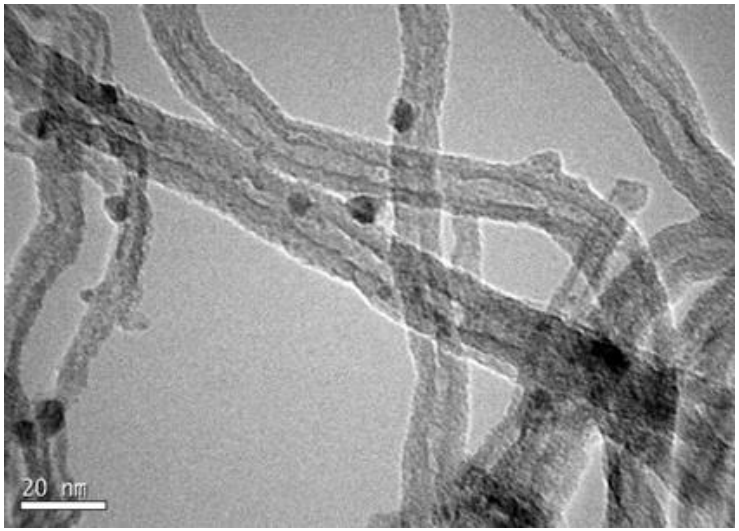

(F)

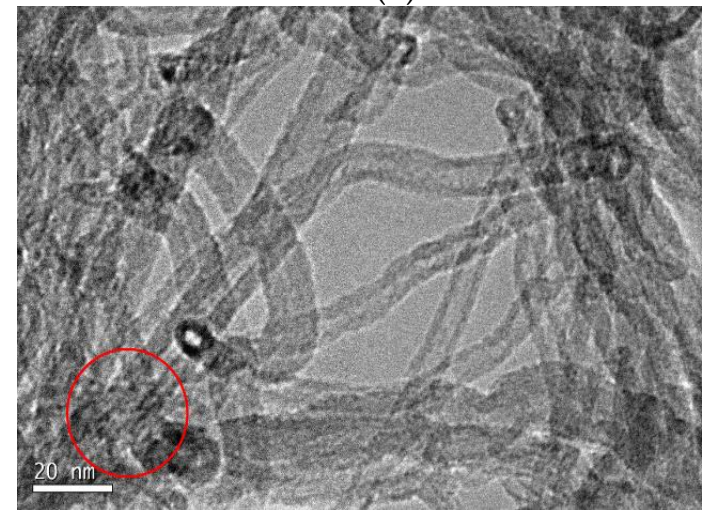

(H)

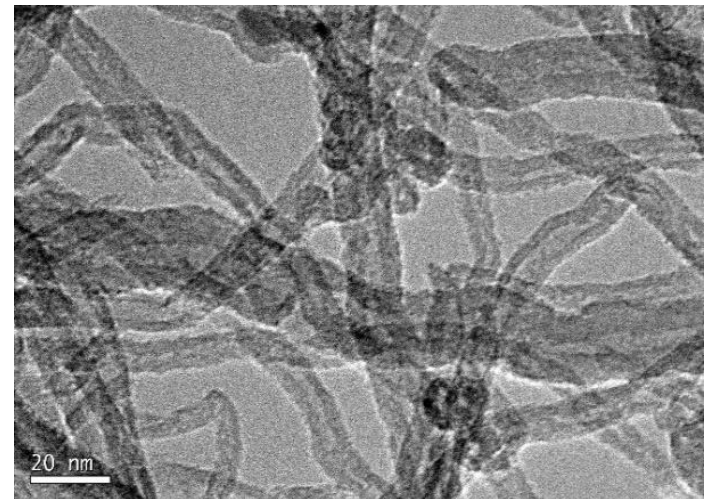

$(\mathrm{J})$

Figure 2. HRTEM images of $\mathrm{Fe}_{100-\mathrm{x}} \mathrm{Cu}_{\mathrm{x}} / \mathrm{CNT}$. (A,B): $\mathrm{Fe}_{100} / \mathrm{CNT}$; (C,D): $\mathrm{Fe}_{75} \mathrm{Cu}_{25} / \mathrm{CNT}$; (E,F): $\mathrm{Fe}_{50} \mathrm{Cu}_{50} / \mathrm{CNT}$; $(\mathbf{G}, \mathbf{H}): \mathrm{Fe}_{25} \mathrm{Cu}_{75} / \mathrm{CNT}$ and $(\mathbf{I}, \mathbf{J})$ : $\mathrm{Cu}_{100} / \mathrm{CNT}$. The presence of $\mathrm{Cu}$ and/or $\mathrm{Cu}_{2} \mathrm{O}$ particles is marked with red circles in Figures $(\mathbf{G}-\mathbf{I})$.

\subsection{Adsorption of Paracetamol}

The kinetics of adsorption of paracetamol for the samples is displayed in Figure 3. The $\mathrm{pH}$ of paracetamol solution was about 6.2-6.6, which determines that under these conditions, the paracetamol is in its molecular form. As a result, the adsorption of the organic was produced through weak dispersed forces. Notice that a rapid adsorption occurred in the initial times, in such way that the adsorption equilibrium seemed to be reached at $30 \mathrm{~min}$, and from this time the adsorbed amount kept constant or increased only slightly. The samples that adsorb less paracetamol were those showing the lowest $\mathrm{S}_{\text {mic }}$ values, that is, $\mathrm{Fe}_{50} \mathrm{Cu}_{50} / \mathrm{CNT}$ and $\mathrm{Fe}_{25} \mathrm{Cu}_{75} / \mathrm{CNT}$. Although the microporosity of these samples was very low or even null, between $11.5 \%$ and $14.6 \%$ of organic was adsorbed. It should be noticed 
that the surface of carbon nanotubes had a proportion of basal planes [39] and as a consequence, $\pi-\pi$ interactions between carbon nanotubes surfaces and paracetamol aromatic rings must be important in the adsorption process on these materials. For the catalysts containing more micropores, the proportion of basal planes was higher and the $\pi-\pi$ interactions would be more relevant. However, the trend observed in the adsorption capacity was not the same that the followed by $S_{\text {mic }}$ values; therefore, other factors such as the surface chemistry or the different crystalline phases cannot be discarded in the adsorption process.

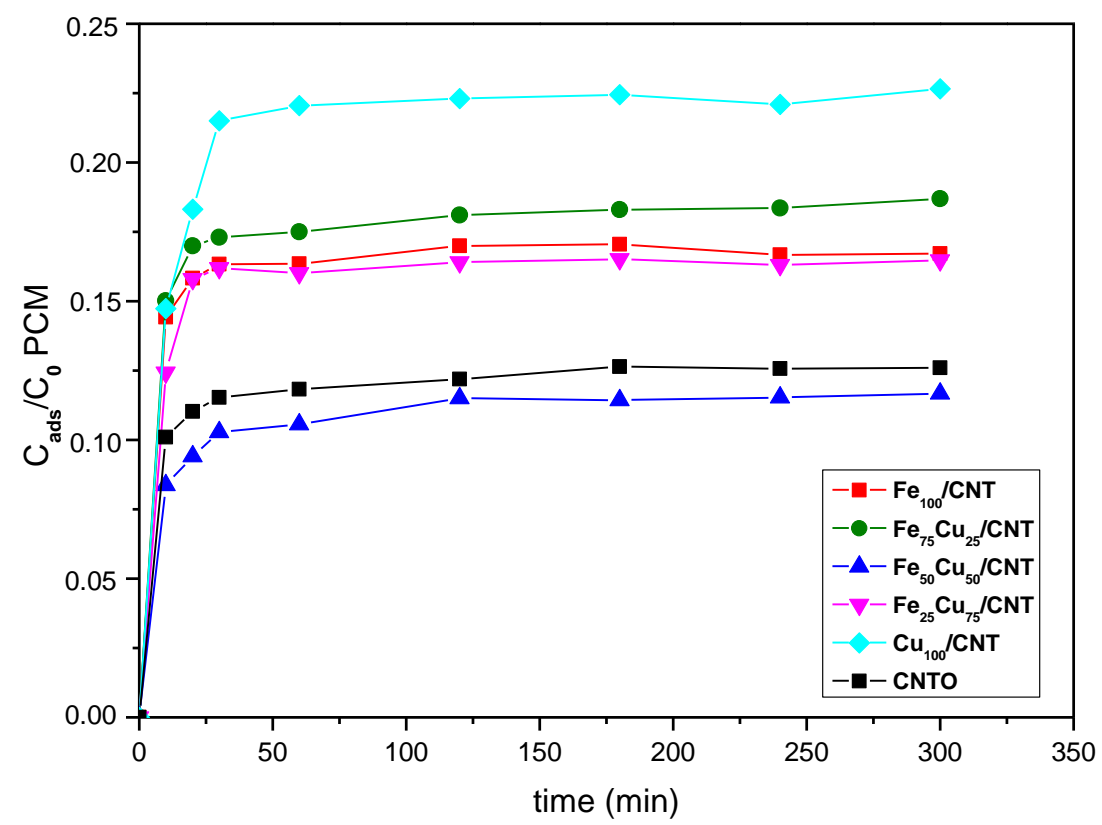

Figure 3. Adsorption kinetics of paracetamol (PCM; $\mathrm{C}_{0}=50 \mathrm{mg} / \mathrm{L}$ ) at $25{ }^{\circ} \mathrm{C}$ on $\mathrm{CNTO}$ and $\mathrm{Fe}_{100-} \mathrm{Cu}_{\mathrm{x}} / \mathrm{CNT}$ samples.

As shown in Figure 3, catalysts adsorb between $11.8 \%$ and $22.5 \%$ of paracetamol at $300 \mathrm{~min}$. However, as said above, the adsorbed amount practically kept constant from $30 \mathrm{~min}$. For that reason, $30 \mathrm{~min}$ was selected as the time for equilibrating adsorption process before adding the $\mathrm{H}_{2} \mathrm{O}_{2}$ in the experiments of degradation of paracetamol.

\subsection{Decomposition of $\mathrm{H}_{2} \mathrm{O}_{2}$}

The capacity of the carbon nanotubes for the decomposition of $\mathrm{H}_{2} \mathrm{O}_{2}$ to produce hydroxyl radicals was investigated (Figure 4). It is known that both couples of species, $\mathrm{Fe}^{3+} / \mathrm{Fe}^{2+}$ and $\mathrm{Cu}^{2+} / \mathrm{Cu}^{+}$are active in heterogeneous Fenton reactions as follows (where $S$ represents the surface of the catalysts) [22,35]:

$$
\begin{aligned}
& \mathrm{S}-\mathrm{Fe}^{2+}+\mathrm{H}_{2} \mathrm{O}_{2} \rightarrow \mathrm{S}^{2} \mathrm{Fe}^{3+}+\mathrm{HO}^{\bullet}+\mathrm{HO}^{-} \\
& \mathrm{S}-\mathrm{Fe}^{3+}+\mathrm{H}_{2} \mathrm{O}_{2} \rightarrow \mathrm{S}-\mathrm{Fe}^{2+}+\mathrm{HO}_{2}{ }^{\bullet}+\mathrm{H}^{+} \\
& \mathrm{S}-\mathrm{Fe}^{2+}+\mathrm{HO}^{\bullet} \rightarrow \mathrm{S}-\mathrm{Fe}^{3+}+\mathrm{HO}^{-} \\
& \mathrm{S}-\mathrm{Fe}^{3+}+\mathrm{HO}_{2}{ }^{\bullet} \rightarrow \mathrm{S}-\mathrm{Fe}^{2+}+\mathrm{O}_{2}+\mathrm{H}^{+} \\
& \mathrm{S}-\mathrm{Cu}^{+}+\mathrm{H}_{2} \mathrm{O}_{2} \rightarrow \mathrm{S}-\mathrm{Cu}^{2+}+\mathrm{HO}^{\bullet}+\mathrm{HO}^{-} \\
& \mathrm{S}-\mathrm{Cu}^{2+}+\mathrm{H}_{2} \mathrm{O}_{2} \rightarrow \mathrm{S}-\mathrm{Cu}^{+}+\mathrm{HO}_{2}{ }^{\bullet}+\mathrm{H}^{+} \\
& \mathrm{S}-\mathrm{Cu}^{+}+\mathrm{HO}^{\bullet} \rightarrow \mathrm{S}-\mathrm{Cu}^{2+}+\mathrm{HO}^{-} \\
& \mathrm{S}-\mathrm{Cu}^{2+}+\mathrm{HO}_{2}{ }^{\bullet} \rightarrow \mathrm{S}-\mathrm{Cu}^{+}+\mathrm{O}_{2}+\mathrm{H}^{+}
\end{aligned}
$$




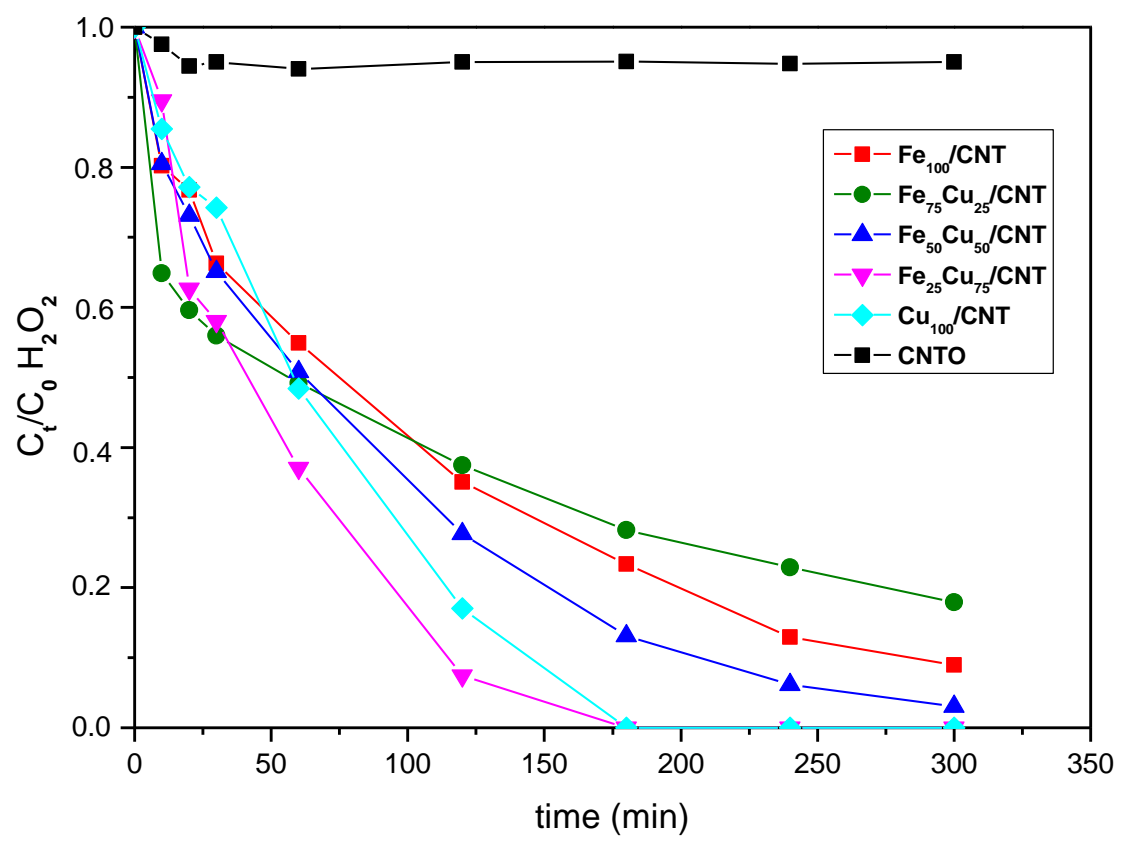

Figure 4. Decomposition kinetics of $\mathrm{H}_{2} \mathrm{O}_{2}\left(\mathrm{C}_{0}=13.8 \times 10^{-3} \mathrm{~mol} / \mathrm{L}\right)$ in absence of paracetamol at $25^{\circ} \mathrm{C}$ on $\mathrm{CNTO}$ and $\mathrm{Fe}_{100-\mathrm{x}} \mathrm{Cu}_{\mathrm{x}} / \mathrm{CNT}$ samples.

As deduced from Figure 4, the followed order in the decomposition of $\mathrm{H}_{2} \mathrm{O}_{2}$ was $\mathrm{Fe}_{75} \mathrm{Cu}_{25} / \mathrm{CNT}$ $<\mathrm{Fe}_{100} / \mathrm{CNT}<\mathrm{Fe}_{50} \mathrm{Cu}_{50} / \mathrm{CNT}<\mathrm{Cu}_{100} / \mathrm{CNT}<\mathrm{Fe}_{25} \mathrm{Cu}_{75} / \mathrm{CNT}$. The most active samples were those containing higher amounts of copper, but among them, the best catalyst was that containing also iron, indicating a synergetic effect between the two metals. Copper seems to result in being more active than iron in this reaction. This could be due to the fact that the $\mathrm{Cu}^{+} / \mathrm{Cu}^{2+} / \mathrm{H}_{2} \mathrm{O}_{2}$ system can work over a broader $\mathrm{pH}$ range, as compared to the $\mathrm{Fe}^{2+} / \mathrm{Fe}^{3+} / \mathrm{H}_{2} \mathrm{O}_{2}$ system. Notice that the decomposition of $\mathrm{H}_{2} \mathrm{O}_{2}$ in our work was carried out at the natural $\mathrm{pH}$ of paracetamol solution, i.e., near neutral conditions and the $\mathrm{Fe}^{2+} / \mathrm{Fe}^{3+}$ usually works in the 3-4 $\mathrm{pH}$ range. In this sense, $\mathrm{Cu}_{100} / \mathrm{CNT}$ decomposed completely the $\mathrm{H}_{2} \mathrm{O}_{2}$ in $180 \mathrm{~min}$, in contrast to the $22 \%$ of remaining $\mathrm{H}_{2} \mathrm{O}_{2}$ observed for $\mathrm{Fe}_{100} / \mathrm{CNT}$ at that time. Notice also that CNTO only decomposed a $5 \%$ of $\mathrm{H}_{2} \mathrm{O}_{2}$ in all the reaction time, which indicates the activity of the incorporated metals $(\mathrm{Fe}-\mathrm{Cu})$ in the Fenton-like reaction under study.

It has been reported that the activity of the catalysts containing iron in the heterogeneous Fenton process depends on characteristics of these oxides, such as crystallinity and surface areas $[40,41]$. The order observed in the decomposition of $\mathrm{H}_{2} \mathrm{O}_{2}$ for our catalysts was not the followed by the microporosity of samples (see $\mathrm{S}_{\text {mic }}$ values in Table 3 ). This means that the catalytic activity was not significantly affected by textural properties and other different factors seem to be involved in it.

As said above, the most active samples were those containing a higher amount of copper, especially $\mathrm{Fe}_{25} \mathrm{Cu}_{75} / \mathrm{CNT}$ and $\mathrm{Cu}_{100} / \mathrm{CNT}$, for which $\mathrm{Cu}_{2} \mathrm{O}$ and $\mathrm{Cu}^{0}$ were detected by XRD. In the case of $\mathrm{Fe}_{50} \mathrm{Cu}_{50} / \mathrm{CNT}$, less active than the former catalysts, $\mathrm{Cu}_{2} \mathrm{O}$ was not detected, but only metallic copper (in addition of $\mathrm{Fe}_{3} \mathrm{O}_{4}$ ), which suggests that $\mathrm{Cu}_{2} \mathrm{O}$, with the presence of $\mathrm{Cu}^{+}$, which can be oxidized to $\mathrm{Cu}^{2+}$ and generate $\mathrm{HO}^{\bullet}$ by Equation (8), was more active than $\mathrm{Cu}^{0}$ in this reaction. With respect to the catalysts containing iron the presence of the $\mathrm{Fe}^{2+} / \mathrm{Fe}^{3+}$ couple in form of $\mathrm{Fe}_{3} \mathrm{O}_{4}$ was also responsible for the decomposition of $\mathrm{H}_{2} \mathrm{O}_{2}$. Since the rate constant of Equation (8) $\left(\mathrm{k}=1.0 \times 10^{4} \mathrm{M}^{-1} \mathrm{~s}^{-1}\right)$ was much higher than that of Equation (4) $\left(\mathrm{k}=76 \mathrm{M}^{-1} \mathrm{~s}^{-1}\right)$ [42], samples containing higher amounts of copper showed higher Fenton-like activity than those containing only iron. Furthermore, the synergic effect between $\mathrm{Cu}$ and $\mathrm{Fe}$ and in general, the better performance of catalysts containing both metals with respect to that of $\mathrm{Fe}_{100} / \mathrm{CNT}$ can also be explained as follows. $\mathrm{Fe}^{3+}$ ions were thermodynamically susceptible to be reduced by $\mathrm{Cu}^{+}$ions (Equation (12)). The redox reaction of $\mathrm{Cu}^{+} / \mathrm{Fe}^{3+}$ will accelerate 
the redox reactions of both $\mathrm{Cu}^{+} / \mathrm{Cu}^{2+}$ and $\mathrm{Fe}^{2+} / \mathrm{Fe}^{3+}$, thus promoting the overall Fenton reaction cycle, and as a result, improving the catalytic rate.

$$
\mathrm{Cu}^{+}+\mathrm{Fe}^{3+} \rightarrow \mathrm{Cu}^{2+}+\mathrm{Fe}^{2+}
$$

This synergic effect was also reported in the degradation of bisphenol A by Wang et al. [22] who found that the catalytic activity of iron-copper bimetallic nanoparticles embedded within ordered mesoporous carbon composite (CuFe-MC) was much higher than that of Fe-MC and Cu-MC.

\subsection{Fenton-like Decomposition of Paracetamol}

The kinetics of catalytic decomposition of paracetamol is depicted in Figure 5. A blank experiment of degradation of paracetamol by $\mathrm{H}_{2} \mathrm{O}_{2}$ in the absence of catalyst was also carried out, and as seen in Figure S4 its degradation was negligible, in this way discarding a direct reaction between both compounds. Two stages were observed in the kinetics of Figure 5 . The first one, until $30 \mathrm{~min}$, was due to the physisorption of paracetamol on carbon nanotubes surface, and the values of removed paracetamol (between $7.5 \%$ and $23 \%$ ) were similar to those reported in Figure 3. The second stage produced after the addition of $\mathrm{H}_{2} \mathrm{O}_{2}$ corresponded to the paracetamol decomposition by the Fenton-like process.

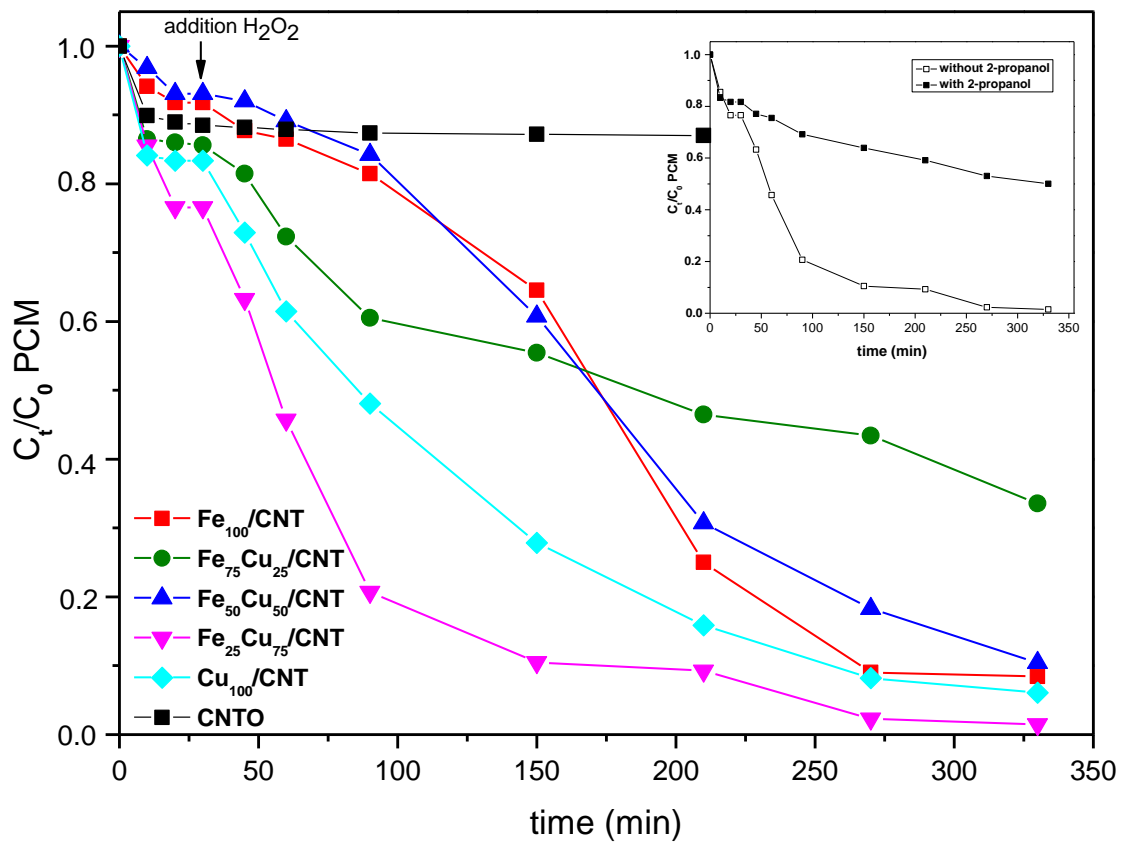

Figure 5. Decomposition kinetics of paracetamol (PCM; $\left.\mathrm{C}_{0}=50 \mathrm{mg} / \mathrm{L}\right)$ at $25^{\circ} \mathrm{C}$ on $\mathrm{Fe}_{100-\mathrm{x}} \mathrm{Cu}_{\mathrm{x}} / \mathrm{CNT}$ samples. $\mathrm{C}_{0}$ of $\mathrm{H}_{2} \mathrm{O}_{2}: 13.8 \times 10^{-3} \mathrm{~mol} / \mathrm{L}$. Initial pH: 6.3-6.6. Inset: Decomposition kinetics of PCM for $\mathrm{Fe}_{25} \mathrm{Cu}_{75} / \mathrm{CNT}$ catalyst in the presence and absence of 2-propanol.

As seen in Figure 5, the CNTO did not decompose the PCM and its removal was produced only by adsorption, and a decrease in the paracetamol concentration was not produced after adding $\mathrm{H}_{2} \mathrm{O}_{2}$. The degradation kinetics of paracetamol, considering only the Fenton-like contribution, and not the adsorption step, were adjusted to pseudo-first-order reaction kinetics, according to Equation (13):

$$
\ln \left(C_{t} / C_{0}\right)=-k_{\text {obs }} t
$$

where $\mathrm{k}_{\mathrm{obs}}$ is the pseudo-first-order apparent rate constant, and the constants were calculated from the slopes of the straight lines by plotting $\ln \left(C_{t} / C_{0}\right)$ as a function of removal time ( $t$; Figure 6$)$. As deduced from the values of the constants (Table 4), the order in the kinetics decomposition of paracetamol was $\mathrm{Fe}_{75} \mathrm{Cu}_{25} / \mathrm{CNT}<\mathrm{Fe}_{50} \mathrm{Cu}_{50} / \mathrm{CNT}<\mathrm{Fe}_{100} / \mathrm{CNT}<\mathrm{Cu}_{100} / \mathrm{CNT}<\mathrm{Fe}_{25} \mathrm{Cu}_{75} / \mathrm{CNT}$. This order was not the 
same than the followed in the decomposition of $\mathrm{H}_{2} \mathrm{O}_{2}$ in Figure 4. Based on our previous results [13], we thought that the amount of decomposed $\mathrm{H}_{2} \mathrm{O}_{2}$ in the presence of paracetamol could be different than in its absence, and therefore, it would affect to the amount of oxidized paracetamol. In order to check it, during the experiments of degradation of the organic we also registered the decomposition curves of $\mathrm{H}_{2} \mathrm{O}_{2}$, which are represented in Figure S4. By comparison of Figure $\mathrm{S} 4$ and Figure 4, it was deduced that in all cases the $\mathrm{H}_{2} \mathrm{O}_{2}$ was decomposed in a less extent in the presence of contaminant than if its absence, and the differences in the rates of decomposition were especially more significant at longer reaction times. It can be explained considering that a competitive effect between paracetamol and $\mathrm{H}_{2} \mathrm{O}_{2}$ by the active species of the catalysts must occur. Similar results were found by us for the decomposition of paracetamol by some perovskites containing copper [13] and by other authors for the decomposition of other organics $[35,43]$.

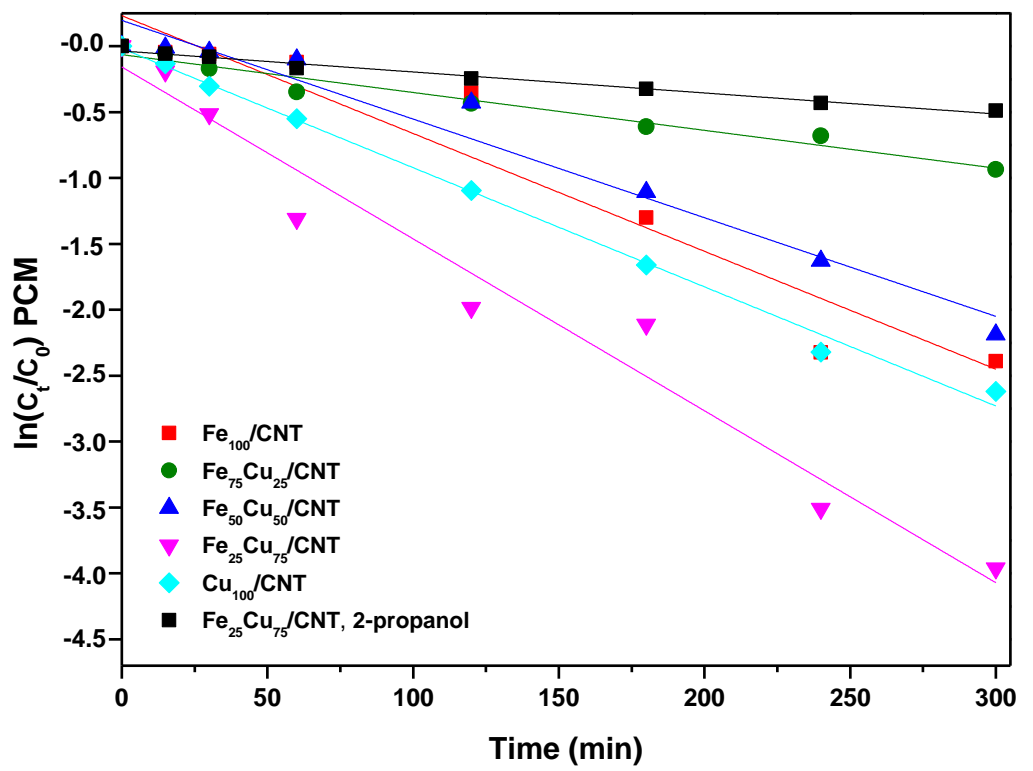

Figure 6. Plots of $\ln \left(\mathrm{C}_{\mathrm{t}} / \mathrm{C}_{0}\right)$ versus time for the paracetamol $\left(\mathrm{C}_{0}=50 \mathrm{mg} / \mathrm{L}\right)$ at $25^{\circ} \mathrm{C}$ on $\mathrm{Fe}_{100-\mathrm{x}} \mathrm{Cu}_{\mathrm{x}} / \mathrm{CNT}$ samples. $\mathrm{C}_{0}$ of $\mathrm{H}_{2} \mathrm{O}_{2}: 13.8 \times 10^{-3} \mathrm{~mol} / \mathrm{L}$.

Table 4. Values of apparent constants for pseudo-first-order kinetics of paracetamol decomposition. $\mathrm{C}_{0}$ of paracetamol: $50 \mathrm{mg} / \mathrm{L}$.

\begin{tabular}{|c|c|c|c|c|}
\hline & $\begin{array}{c}\mathrm{pH}=6.3-6.6 \\
\mathrm{C}_{0} \mathrm{H}_{2} \mathrm{O}_{2}=13.8 \times 10^{-3} \mathrm{~mol} / \mathrm{L}\end{array}$ & $\mathrm{C}_{0} \mathrm{H}_{2} \mathrm{O}_{2}=$ & $10^{-3} \mathrm{~mol} / \mathrm{L}$ & $\begin{aligned} \mathrm{pH} & =6.3-6.6 \\
\mathrm{C}_{0} \mathrm{H}_{2} \mathrm{O}_{2} & =6.9 \times 10^{-3} \mathrm{~mol} / \mathrm{L}\end{aligned}$ \\
\hline Catalyst & $k\left(h^{-1}\right)$ & $k_{1}\left(h^{-1}\right) *$ & $k_{2}\left(h^{-1}\right) *$ & $k\left(h^{-1}\right)$ \\
\hline $\mathrm{Fe}_{100} / \mathrm{CNT}$ & 0.53 & 7.36 & 0.34 & $0.15\left(\mathrm{k}_{1}^{*}\right), 1.05\left(\mathrm{k}_{2}^{*}\right)$ \\
\hline $\mathrm{Fe}_{75} \mathrm{Cu}_{25} / \mathrm{CNT}$ & 0.17 & 4.20 & 0.03 & 0.05 \\
\hline $\mathrm{Fe}_{50} \mathrm{Cu}_{50} / \mathrm{CNT}$ & 0.45 & 2.15 & 0.22 & 0.10 \\
\hline $\mathrm{Fe}_{25} \mathrm{Cu}_{75} / \mathrm{CNT}$ & 0.78 & 2.29 & 0.06 & 0.29 \\
\hline $\mathrm{Cu}_{100} / \mathrm{CNT}$ & 0.54 & 0.61 & 0.005 & 0.12 \\
\hline
\end{tabular}

* Constants for the two stages observed in the kinetic curves.

As deduced from Figure 5, $\mathrm{Fe}_{100-\mathrm{x}} \mathrm{Cu}_{\mathrm{x}} / \mathrm{CNT}$ samples were efficient catalysts for the Fenton-like decomposition of paracetamol. Removal of this compound between $90.2 \%$ and $98.3 \%$ were achieved after $5 \mathrm{~h}$ of reaction (330 min including the adsorption step) for all the catalysts, except for $\mathrm{Fe}_{75} \mathrm{Cu}_{25} / \mathrm{CNT}$ (67\% of paracetamol removal). These values were even higher than those obtained previously by us using mesoporous carbons containing iron (78-96\%, with a percentage removed by adsorption between $20 \%$ and $60 \%$ ) [21]. Furthermore, for the samples containing higher amounts of copper, that is, $\mathrm{Cu}_{100} / \mathrm{CNT}$ and $\mathrm{Fe}_{25} \mathrm{Cu}_{75} / \mathrm{CNT}$, depletion values of $73.2 \%$ and $87.8 \%$, respectively, were achieved in only $2 \mathrm{~h}$ of reaction. 
According to Figure S4, the final amounts of decomposed $\mathrm{H}_{2} \mathrm{O}_{2}$ in presence of paracetamol for $\mathrm{F}_{100} / \mathrm{CNT}, \mathrm{Cu}_{100} / \mathrm{CNT}$ and $\mathrm{Fe}_{25} \mathrm{Cu}_{75} / \mathrm{CNT}$ samples were very similar (between $75 \%$ and $80 \%$ ) and the amounts or removed paracetamol for these three catalysts (between $92.3 \%$ and $98.3 \%$ ) were also very close between them. However, in the case of $\mathrm{Fe}_{75} \mathrm{Cu}_{25} / \mathrm{CNT}$, for which a degradation of paracetamol of $90.3 \%$ was achieved, the amount of decomposed $\mathrm{H}_{2} \mathrm{O}_{2}(53 \%)$ was significantly lower than for the former catalysts. It means that not all the decomposed hydrogen peroxide participated in the oxidation of paracetamol by Equation (14), but some of the generated $\mathrm{HO}^{\bullet}$ could react with more $\mathrm{H}_{2} \mathrm{O}_{2}$ by Equation (15), producing an additional decomposition of $\mathrm{H}_{2} \mathrm{O}_{2}$.

$$
\begin{gathered}
\text { Paracetamol }+\mathrm{HO}^{\bullet} \rightarrow \mathrm{R}^{\bullet}+\mathrm{H}_{2} \mathrm{O} \rightarrow \ldots \rightarrow \mathrm{CO}_{2}+\mathrm{H}_{2} \mathrm{O} \\
\mathrm{H}_{2} \mathrm{O}_{2}+\mathrm{HO}^{\bullet} \rightarrow \mathrm{H}_{2} \mathrm{O}+\mathrm{HO}_{2}^{\bullet}
\end{gathered}
$$

It has been proposed that $\mathrm{HO} \cdot$ radicals are considered as the dominant reactive oxygen species (ROS) in Fenton-like systems. In order to check if these radicals are also the main ROS in our case, a radical scavenger assay was carried out, by testing $\mathrm{Fe}_{25} \mathrm{Cu}_{75} / \mathrm{CNT}$ in the presence of 2-propanol. As shown in the inset of Figure 5, the removal of paracetamol was strongly inhibited with the presence of the stoichiometric amount of 2-propanol $\left(13.8 \times 10^{-3} \mathrm{M}\right)$ with respect to $\mathrm{H}_{2} \mathrm{O}_{2}$, and the calculated apparent rate constant was significantly reduced from 0.78 to $0.096 \mathrm{~h}^{-1}$, suggesting that $\mathrm{HO}^{\bullet}$ was the dominant ROS in this study.

\subsubsection{Leaching and Mineralization Degree}

Determination of leaching of iron and copper was carried out in order to study the possible contribution of homogeneous Fenton to the degradation of paracetamol. The amounts of metals leached off into the aqueous solution after $5 \mathrm{~h}$ of reaction, expressed in $\mathrm{mg} / \mathrm{L}$, are listed in Table 5 . Notice that the concentration of catalyst used in the reaction was $0.4 \mathrm{~g} / \mathrm{L}$. When the reaction was carried out at natural $\mathrm{pH}$, for the mixed catalysts, the amount of leached iron, comprised between 0.1 and $0.58 \mathrm{mg} / \mathrm{L}$ were below EU guidelines (<2 ppm) [44]. In the case of Fe100/CNT the leaching of iron was higher, $3.99 \mathrm{mg} / \mathrm{L}$; however, it was significantly lower than the values obtained by other authors using $\mathrm{Fe}_{3} \mathrm{O}_{4} / \mathrm{MWCNT}$ in the degradation of phenol and $p$-nitrophenol (5.25 mg/L) [28] and acid Orange II (29.3\% of leached iron) [5]. As a contrast, the amount and percentage of leached copper in the mixed samples were much higher than those values for iron. When comparing catalysts containing only one component, the amount of lixiviated copper in $\mathrm{Cu}_{100} / \mathrm{CNT}$ was lower than that of leached iron in $\mathrm{Fe}_{100} / \mathrm{CNT}$. The opposite occurs if reaction was carried out at $\mathrm{pH} 3$. The leaching of both iron and copper increased when decreasing $\mathrm{pH}$, but that for copper did it to a greater extent (from 2.17 to $18.61 \mathrm{mg} / \mathrm{L})$, resulting in approximately the double of leached copper with respect to iron.

Table 5. Leaching of metals after $5 \mathrm{~h}$ of reaction determined by inductively coupled plasma mass spectrometry (ICP-MS).

\begin{tabular}{ccccc}
\hline Catalyst & $\begin{array}{c}\text { Leaching of Iron } \\
(\mathbf{m g} / \mathbf{L})\end{array}$ & $\begin{array}{c}\text { Leaching of Iron * } \\
\mathbf{( \% )}\end{array}$ & $\begin{array}{c}\text { Leaching of Copper } \\
(\mathbf{m g} / \mathbf{L})\end{array}$ & $\begin{array}{c}\text { Leaching of Copper * } \\
(\mathbf{\%})\end{array}$ \\
\hline $\mathrm{Fe}_{100} / \mathrm{CNT}$ & 3.99 & 17 & - & - \\
$\mathrm{Fe}_{75} \mathrm{Cu}_{25} / \mathrm{CNT}$ & 0.10 & 0.5 & 2.26 & 29.2 \\
$\mathrm{Fe}_{50} \mathrm{Cu}_{50} / \mathrm{CNT}$ & 0.58 & 4.95 & 10.56 & 69.1 \\
$\mathrm{Fe}_{25} \mathrm{Cu}_{55} / \mathrm{CNT}$ & 0.10 & 1.4 & 10.57 & 40.6 \\
$\mathrm{Cu}_{100} / \mathrm{CNT}$ & - & - & 2.17 & 6.7 \\
$\mathrm{Fe}_{100} / \mathrm{CNT}, \mathrm{pH} 3$ & 9.25 & 39.4 & - & - \\
$\mathrm{Cu}_{100} / \mathrm{CNT}, \mathrm{pH} 3$ & - & - & 18.61 & 57.6 \\
\hline
\end{tabular}

* Percentage of metal leached off with respect to the initial content in the carbon nanotubes catalysts.

In order to evaluate the mineralization degree of paracetamol, the TOC values were measured. From the results of Table 6, mineralization degree increased with reaction time; however, the TOC 
reduction was lower than the corresponding to the paracetamol removal (Figure 5), indicating that this compound was transformed upon oxidation to intermediate products. These products could be some different carboxylic acids, such as ketomalonic, maleic, fumaric, oxalic, oxamic and succinic, which have been reported by different authors $[45,46]$ as products of photo- or electrochemical degradation of the paracetamol. The presence of these acids could explain the decrease in the $\mathrm{pH}$ values of solutions along reaction time (Table 5). However, some additional experiments of monitoring of the decomposition products by mass spectrometry should be addressed in future works in order to check this assumption. For some of samples the TOC removal was higher than the obtained $(60 \%)$ when paracetamol was decomposed by using a zeolite containing iron [47] and those reached $(35-50 \%)$ in the presence of nanoparticles of iron at $\mathrm{pH}=2.6$ [38]. Furthermore, in those studies the reaction conditions were much more drastic than that used in our work. Other TOC removal values obtained previously by us for the degradation of paracetamol after $5 \mathrm{~h}$ were $52 \%$ with a $\mathrm{LaCuO}_{3}$ perovskite reference [13] and $45-50 \%$ with some Fe-carbon xerogels $[13,21,38]$, which are also lower than the reported in the present work. Therefore, the $\mathrm{Fe}_{\mathrm{x}} \mathrm{Cu}_{100-x} / \mathrm{CNT}$ samples used are efficient catalysts in this Fenton-like process. From the results of Table 6 , the best catalyst in terms of both removal and mineralization of paracetamol was $\mathrm{Fe}_{25} \mathrm{Cu}_{75} / \mathrm{CNT}$, for which almost all the paracetamol was decomposed and a TOC removal of $85.6 \%$ after 300 min was achieved.

Table 6. Values of total organic carbon (TOC) at different reaction times and values of $\mathrm{pH}$ of the paracetamol solutions before and after reaction. $\mathrm{C}_{0}$ of paracetamol: $50 \mathrm{mg} / \mathrm{L} ; \mathrm{C}_{0}$ of $\mathrm{H}_{2} \mathrm{O}_{2}$ : $13.8 \times 10^{-3} \mathrm{~mol} / \mathrm{L}$.

\begin{tabular}{ccccccc}
\hline & \multicolumn{3}{c}{ TOC (\%) } & \multicolumn{3}{c}{ pH } \\
\hline Catalyst & $\mathbf{1 5}$ min & $\mathbf{6 0}$ min & $\mathbf{1 8 0}$ min & $\mathbf{3 0 0}$ min & Initial & Final \\
\hline $\mathrm{Fe}_{100} / \mathrm{CNT}$ & - & 88.4 & 70.1 & 7.1 & 6.31 & 5.12 \\
$\mathrm{Fe}_{75} \mathrm{Cu}_{25} / \mathrm{CNT}$ & - & 77.9 & 54.5 & 52.5 & 6.31 & 4.53 \\
$\mathrm{Fe}_{50} \mathrm{Cu}_{50} / \mathrm{CNT}$ & 79.9 & 73.7 & 60.3 & 59.4 & 6.31 & 4.92 \\
$\mathrm{Fe}_{25} \mathrm{Cu}_{75} / \mathrm{CNT}$ & 85.6 & 43.7 & 31.3 & 14.4 & 6.60 & 4.35 \\
$\mathrm{Cu}_{100} / \mathrm{CNT}$ & 80.7 & 68.1 & 62.2 & 54.0 & 6.60 & 4.51 \\
\hline
\end{tabular}

\subsubsection{Influence of $\mathrm{pH}$ and Dosage of $\mathrm{H}_{2} \mathrm{O}_{2}$}

In order to check the influence of the $\mathrm{pH}$ of reaction, the initial $\mathrm{pH}$ of solution was modified until $\mathrm{pH} 3$ by addition of $10 \mathrm{wt} \% \mathrm{H}_{2} \mathrm{SO}_{4}$. The kinetics of the decomposition of paracetamol for all the catalysts under this $\mathrm{pH}$ condition is displayed in Figure 7.

Notice that the reaction proceeds better at $\mathrm{pH} 3$ than at natural $\mathrm{pH}$ with the catalysts containing higher amounts of iron and faster decompositions of paracetamol were produced (compare Figures 5 and 7); however, the differences in the final decomposition values of paracetamol at both $\mathrm{pH}$ were not very significant. On the contrary, the performance of catalysts containing higher amount of copper was worse at $\mathrm{pH} 3$ than at the natural $\mathrm{pH}$ of paracetamol solution. In this sense, significantly lower values of decomposition were achieved at acid $\mathrm{pH}, 64 \%$ and $46 \%$ for $\mathrm{Fe}_{25} \mathrm{Cu}_{75} / \mathrm{CNT}$ and $\mathrm{Cu}_{100} / \mathrm{CNT}$, respectively, in contrast to $87.8 \%$ and $73.2 \%$ values obtained for those catalysts at natural $\mathrm{pH}$. Furthermore, at $\mathrm{pH} 3$, the catalytic activity decreased with the increment of the amount of copper in the catalysts. As regarding the kinetic curves, two stages could be clearly differentiated, and their corresponding apparent constants, $\mathrm{k}_{1}$ and $\mathrm{k}_{2}$, are included in Table 4 . A very fast decomposition occurred in the first 15-30 min after the addition of $\mathrm{H}_{2} \mathrm{O}_{2}$, and then the reaction was significantly slowed down. From calculated apparent constants (Table 4) it is seen that the first step of the reaction occurred much faster the higher the iron content in samples was.

Additionally, when compared the performance of $\mathrm{Cu}_{100} / \mathrm{CNT}$ and $\mathrm{Fe}_{100} / \mathrm{CNT}$ at $\mathrm{pH} 3$ (Figure 7), the decomposition of paracetamol achieved with the first catalyst was significantly lower ( $45 \%)$ than that for the second $(100 \%)$, probably due to the higher leaching of copper $(18.61 \mathrm{mg} / \mathrm{L})$ with respect to iron $(9.25 \mathrm{mg} / \mathrm{L}$; see Table 4$)$, which led to a loss of heterogeneous copper active sites. However, as 
said above, for $\mathrm{Fe}_{100} / \mathrm{CNT}$, a faster and higher decomposition of paracetamol occurred at $\mathrm{pH} 3$ with respect to that at natural $\mathrm{pH}$. For this catalyst, the higher amount of leached iron (Table 4) at pH 3 seemed to increase the homogenous contribution to the performance of reaction, also changing the kinetics of reactions, as deduced from the different shape of decomposition curves at the two $\mathrm{pH}$ values. Regarding the TOC values (Table S1), in general the final mineralization degrees achieved when the reaction was carried out at $\mathrm{pH} 3$ were lower than the obtained at $\mathrm{pH}$ 6.2. Therefore, as a whole, it is better to carry out the reaction at the natural $\mathrm{pH}$, in this way avoiding the additional cost of modifying the $\mathrm{pH}$ by adding any acid and decreasing the leached metals.

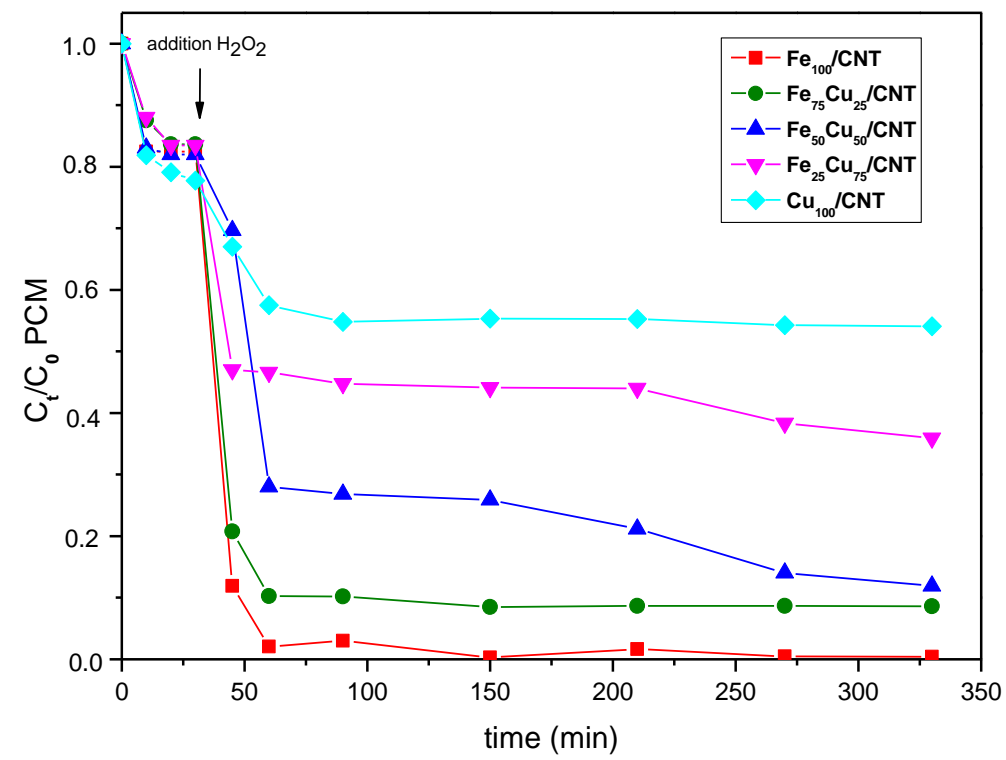

Figure 7. Decomposition kinetics of paracetamol (PCM; $\left.\mathrm{C}_{0}=50 \mathrm{mg} / \mathrm{L}\right)$ at $25^{\circ} \mathrm{C}$ on $\mathrm{Fe}_{100-\mathrm{x}} \mathrm{Cu}_{\mathrm{x}} / \mathrm{CNT}$ samples. $\mathrm{C}_{0}$ of $\mathrm{H}_{2} \mathrm{O}_{2}: 13.8 \times 10^{-3} \mathrm{~mol} / \mathrm{L}$. Initial pH: 3 .

As mentioned in the "Materials and Methods" section, the amount of $\mathrm{H}_{2} \mathrm{O}_{2}$ used in all the experiments was twice the stoichiometric one, according to the previous results. However, we decided to carry out some experiments using the stoichiometric amount, in order to study the influence of the dosage of $\mathrm{H}_{2} \mathrm{O}_{2}$ on the paracetamol decomposition. As deduced from Figure 8, the decomposition values were significantly lower for most of the catalysts when the stoichiometric amount of $\mathrm{H}_{2} \mathrm{O}_{2}$ was used (compare with data from Figure 5) and the apparent constant rate values decreased significantly by a factor of 2.7-4.5 (see Table 4 ).

Thus, the paracetamol decomposition was reduced between a $21 \%$ (for $\mathrm{Fe}_{25} \mathrm{Cu}_{75} / \mathrm{CNT}$ ) and $52 \%$ (for $\mathrm{Fe}_{75} \mathrm{Cu}_{25} / \mathrm{CNT}$ ). The exception was the catalyst containing only iron, i.e., $\mathrm{Fe}_{100} / \mathrm{CNT}$, for which, the final depletion of paracetamol was almost the same for both $\mathrm{H}_{2} \mathrm{O}_{2}$ dosages, although the decomposition occurred faster when the higher amount of oxidant was used. For this catalyst two stages seemed to exist in the heterogeneous Fenton reaction: the induction period and rapid degradation stage, the degradation rates were accelerated after about 90 min after the adding of $\mathrm{H}_{2} \mathrm{O}_{2}$, as clearly seen by the values of the apparent constant rate calculated for both stages (Table 4).

Furthermore, the values of TOC removal were, in general, lower than those obtained when the double of amount of oxidant was used (see Table S2 in Supplementary Materials). Therefore, as a rule, the use of the stoichiometric amount of $\mathrm{H}_{2} \mathrm{O}_{2}$ decreased significantly the decomposition of paracetamol. Notice that $\mathrm{H}_{2} \mathrm{O}_{2}$ acted as a sink for $\mathrm{HO}^{\bullet}$ radicals through Equation (15), decreasing the paracetamol oxidation, and additional $\mathrm{H}_{2} \mathrm{O}_{2}$ amount must be necessary to produce more oxidant radicals through Equations (4), (5), (8) and (9). Consequently, the reaction proceeded better when the $\mathrm{H}_{2} \mathrm{O}_{2}$ amount was the double of the stoichiometric. 


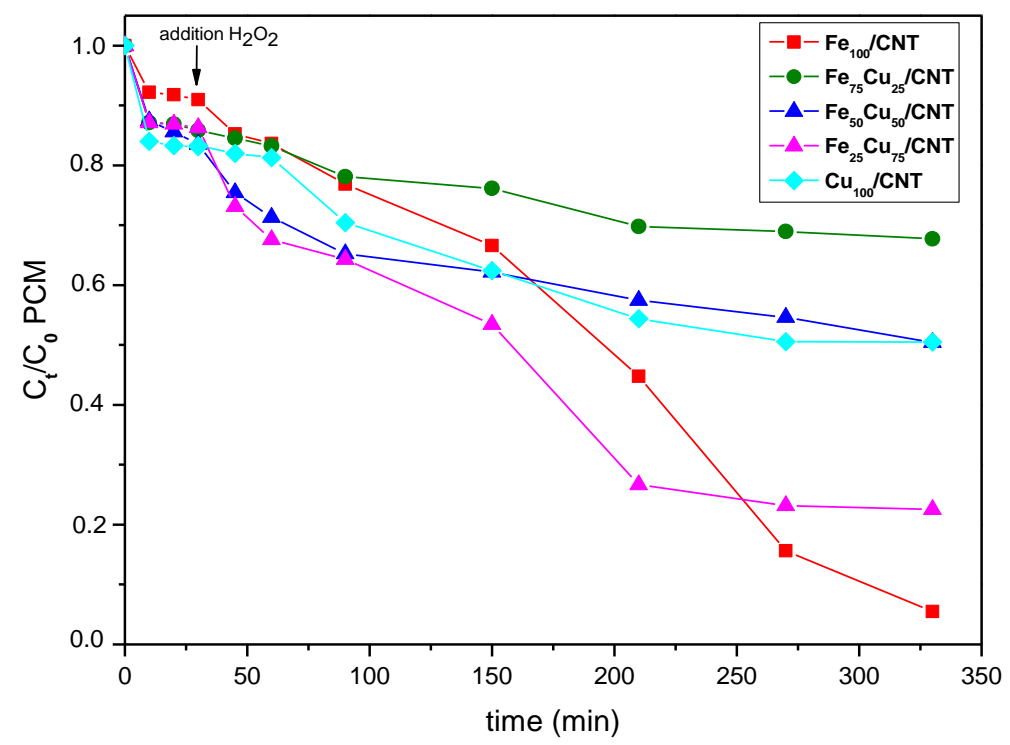

Figure 8. Decomposition kinetics of paracetamol (PCM; $\left.\mathrm{C}_{0}=50 \mathrm{mg} / \mathrm{L}\right)$ at $25^{\circ} \mathrm{C}$ on $\mathrm{Fe}_{100-\mathrm{x}} \mathrm{Cu}_{\mathrm{x}} / \mathrm{CNT}$ samples. $\mathrm{C}_{0}$ of $\mathrm{H}_{2} \mathrm{O}_{2}: 6.9 \times 10^{-3} \mathrm{~mol} / \mathrm{L}$. Initial $\mathrm{pH}$ : 6.3-6.6.

\subsubsection{Recyclability of Catalysts}

Some experiments for studying the recyclability of the catalysts were carried out, more concretely, with three of the catalysts, $\mathrm{Fe}_{100} / \mathrm{CNT}$, $\mathrm{Cu}_{100} / \mathrm{CNT}$ and the most active one, $\mathrm{Fe}_{25} \mathrm{Cu}_{75} / \mathrm{CNT}$. The results of reusability are shown in Figure 9.
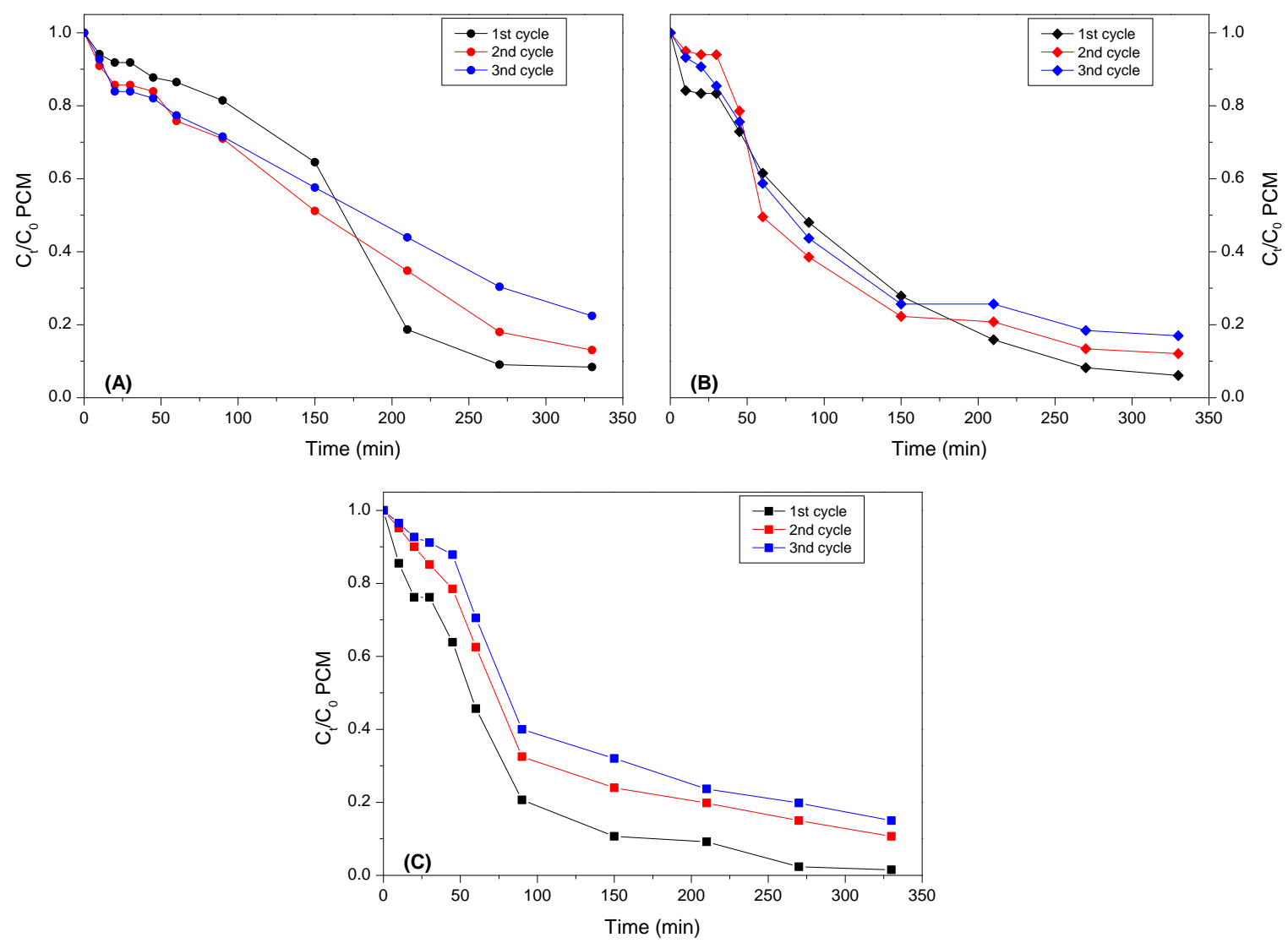

Figure 9. Recyclability of catalysts for the degradation of paracetamol (PCM). (A): $\mathrm{Fe}_{100} / \mathrm{CNT}$; (B): $\mathrm{Cu}_{100} / \mathrm{CNT}$ and (C): $\mathrm{Fe}_{25} \mathrm{Cu}_{75} / \mathrm{CNT}$. 
Notice that a decrease in the activity around $5-6 \%$ in the case of $\mathrm{Fe}_{100} / \mathrm{CNT}$ and $\mathrm{Cu}_{100} / \mathrm{CNT}$, and about $10 \%$ for $\mathrm{Fe}_{25} \mathrm{Cu}_{75} / \mathrm{CNT}$ was produced for the first to the second cycle, probably due to the leaching of metals into solution (Table 4). The reduction of activity after three runs was comprised between $12 \%$ (for $\mathrm{Cu}_{100} / \mathrm{CNT}$ ) and $15 \%$ (for $\mathrm{Fe}_{100} / \mathrm{CNT}$ and $\mathrm{Fe}_{25} \mathrm{Cu}_{75} / \mathrm{CNT}$ ). However, despite the leaching of metals and the decrease in the activity, the TOC removal values were still significant and values between $45 \%$ and $78 \%$ of mineralization of paracetamol were achieved with recycled catalysts (Table S2). Therefore, the amount of remaining active sites in the catalysts was still enough to carry out the reaction in consecutive cycles.

\section{Conclusions}

In this work, we reported for the first time the preparation of Fe-Cu doped carbon nanotubes by an easy method and their application as efficient catalysts for the degradation of paracetamol (90-98\% in $5 \mathrm{~h}$ ) by a combined process of adsorption and Fenton-like oxidation under mild reaction conditions, $25^{\circ} \mathrm{C}$ and $\mathrm{pH}$ nearly neutral. The catalysts containing higher amounts of copper, present as $\mathrm{Cu}_{2} \mathrm{O}$ and $\mathrm{Cu}$, showed higher Fenton-like activity than those containing only iron, as $\mathrm{Fe}_{3} \mathrm{O}_{4}$. It could be explained by the higher rate constant of reaction $\mathrm{Cu}^{+} / \mathrm{H}_{2} \mathrm{O}_{2}$, with respect to that of $\mathrm{Fe}^{2+} / \mathrm{H}_{2} \mathrm{O}_{2}$, which should produce more $\mathrm{HO}^{\bullet}$ oxidant radicals in the case of catalyst with more copper. Additionally, a synergic effect between both $\mathrm{Cu}^{+} / \mathrm{Cu}^{2+}$ and $\mathrm{Fe}^{2+} / \mathrm{Fe}^{3+}$ was produced, and as a result, $\mathrm{Fe}_{25} \mathrm{Cu}_{75} / \mathrm{CNT}$ was more active than the catalyst with only copper, i.e., $\mathrm{Cu}_{100} / \mathrm{CNT}$. That catalyst was the best in terms of both removal and mineralization of paracetamol, for which the paracetamol was almost completely decomposed and a TOC removal of $85.6 \%$ after $5 \mathrm{~h}$ was achieved. The reaction proceeds in all cases better when the $\mathrm{H}_{2} \mathrm{O}_{2}$ amount was double that of the stoichiometric one. The acidification of initial solution until $\mathrm{pH} 3$ exerted a positive effect on the paracetamol degradation when the catalysts containing high amounts of iron were used (probably due to the homogeneous contribution of leached iron) and a negative effect for the samples doped with higher amounts of copper. As a result of the leaching of metals, a decrease of paracetamol degradation around $12-15 \%$ occurred from the first to the third reaction cycle. However, the activity and the mineralization degree remained high. These catalysts could be extended to the Fenton-like removal of other contaminants present in waters.

Supplementary Materials: The following are available online at http://www.mdpi.com/2079-4991/10/4/749/s1, Figure S1: Isotherms of adsorption-desorption of $\mathrm{Fe}_{100-x} \mathrm{Cu}_{x} / \mathrm{CNT}$ samples. Figure S2: EDX spectra from TEM images of CNTO and $\mathrm{Fe}_{100-x} \mathrm{Cu}_{x} / \mathrm{CNT}$ samples. Figure S3: SEM images of $\mathrm{Fe}_{100-\mathrm{x}} \mathrm{Cu}_{\mathrm{x}} / \mathrm{CNT}$ samples and corresponding EDX spectra. Figure S4: Decomposition kinetics of $\mathrm{H}_{2} \mathrm{O}_{2}\left(\mathrm{C}_{0}=13.8 \times 10^{-3} \mathrm{~mol} / \mathrm{L}\right)$ in the presence of paracetamol $\left(\mathrm{C}_{0}=50 \mathrm{mg} / \mathrm{L}\right)$ at $25^{\circ} \mathrm{C}$ on $\mathrm{Fe}_{100-x} \mathrm{Cu}_{\mathrm{x}} / \mathrm{CNT}$ samples. Table S1: Values of TOC $(\%)$ obtained at $\mathrm{pH}$ 3 at different reaction times. $\mathrm{C}_{0}$ of paracetamol: $50 \mathrm{mg} / \mathrm{L} ; \mathrm{C}_{0} \mathrm{H}_{2} \mathrm{O}_{2}: 13.8 \times 10^{-3} \mathrm{~mol} / \mathrm{L}$. Table S2: Values of TOC (\%) obtained at natural $\mathrm{pH}$ at different reaction times. $\mathrm{C}_{0}$ of paracetamol: $50 \mathrm{mg} / \mathrm{L}$.

Author Contributions: M.L.R.-C. conceived and designed the experiments. N.B.-B. and I.L.-T. performed the synthesis and characterization of catalysts. M.G.-A. carried out the adsorption and catalytic experiments. A.C.-N. performed the analysis by TEM and SEM of nanomaterials. M.L.R.-C. supervised the experiments, wrote the manuscript. All authors have read and agreed to the published version of the manuscript.

Funding: This work was supported by the Spanish Ministry of Science and Innovation (CTM2014-56668-R) and by European University of Madrid project (2017/UEM09 and 2018/UEM21).

Conflicts of Interest: The authors declare no conflict of interest.

\section{References}

1. Comninellis, C.; Kapalka, A.; Malato, S.; Parsons, S.A.; Poulios, I.; Mantzavinos, D. Advanced oxidation processes for water treatment: Advances and trends for R\&D. J. Chem. Technol. Biotechnol. 2008, 83, 769-776.

2. Gogate, P.R.; Pandit, A.B. A review of imperative technologies for wastewater treatment. I: Oxidation technologies at ambient conditions. Adv. Environ. Res. 2004, 8, 501-551. [CrossRef]

3. Gogate, P.R.; Pandit, A.B. A review of imperative technologies for wastewater treatment. II: Hybrid methods. Adv. Environ. Res. 2004, 8, 553-597. [CrossRef] 
4. Poyatos, J.M.; Munio, M.M.; Almecija, M.C.; Torres, J.C.; Hontoria, E.; Osorio, F. Advanced oxidation processes for wastewater treatment: State of the art. Water Air Soil Pollut. 2010, 205, 187-204. [CrossRef]

5. Rodriguez, A.; Ovejero, G.; Sotelo, J.L.; Mestanza, M.; Garcia, J. Heterogeneous Fenton catalyst supports screening for mono azo dye degradation in contaminated wastewaters. Ind. Eng. Chem. Res. 2010, 49, 498-505. [CrossRef]

6. Rahim Pouran, S.; Abdul Raman, A.A.; Wan Daud, W.M.A. Review on the application of modified iron oxides as heterogeneous catalysts in Fenton reactions. J. Cleaner Prod. 2014, 64, 24-35. [CrossRef]

7. Nidheesh, P.V. Heterogeneous Fenton catalysts for the abatement of organic pollutants from aqueous solution: A review. RSC Adv. 2015, 5, 40552-40577. [CrossRef]

8. Munoz, M.; de Pedro, Z.M.; Casas, J.A.; Rodriguez, J.J. Preparation of magnetite-based catalysts and their application in heterogeneous Fenton oxidation - A review. Appl. Catal. B Environ. 2015, 176-177, 249-265. [CrossRef]

9. He, J.; Yang, X.; Men, B.; Wang, D. Interfacial mechanisms of heterogeneous Fenton reactions catalyzed by iron-based materials: A review. J. Environ. Sci. 2016, 39, 97-109. [CrossRef]

10. Bokare, A.D.; Choi, W. Review of iron-free Fenton-like systems for activating $\mathrm{H}_{2} \mathrm{O}_{2}$ in advanced oxidation processes. J. Hazard. Mater. 2014, 275, 121-135. [CrossRef]

11. Garrido-Ramirez, E.G.; Theng, B.K.G.; Mora, M.L. Clays and oxide minerals as catalysts and nanocatalysts in Fenton-like reactions-A review. Appl. Clay Sci. 2010, 47, 182-192. [CrossRef]

12. Pereira, M.C.; Oliveira, L.C.A.; Murad, E. Iron oxide catalysts: Fenton and Fenton-like reactions-A review. Clay Miner. 2012, 47, 285-302. [CrossRef]

13. Carrasco-Diaz, M.R.; Castillejos-Lopez, E.; Cerpa-Naranjo, A.; Rojas-Cervantes, M.L. Efficient removal of paracetamol using $\mathrm{LaCu}_{1-\mathrm{x}} \mathrm{M}_{\mathrm{x}} \mathrm{O}_{3}(\mathrm{M}=\mathrm{Mn}, \mathrm{Ti})$ perovskites as heterogeneous Fenton-like catalysts. Chem. Eng. J. 2016, 304, 408-418. [CrossRef]

14. Kuznetsova, E.V.; Savinov, E.N.; Vostrikova, L.A.; Parmon, V.N. Heterogeneous catalysis in the Fenton-type system FeZSM-5/ $\mathrm{H}_{2} \mathrm{O}_{2}$. Appl. Catal. B Environ. 2004, 51, 165-170. [CrossRef]

15. Navalon, S.; Alvaro, M.; Garcia, H. Heterogeneous Fenton catalysts based on clays, silicas and zeolites. Appl. Catal. B Environ. 2010, 99, 1-26. [CrossRef]

16. Velichkova, F.; Delmas, H.; Julcour, C.; Koumanova, B. Heterogeneous fenton and photo-fenton oxidation for paracetamol removal using iron containing ZSM-5 zeolite as catalyst. AIChE J. 2017, 63, 669-679. [CrossRef]

17. Ramirez,J.H.; Costa, C.A.; Madeira, L.M.; Mata, G.; Vicente, M.A.; Rojas-Cervantes, M.L.; Lopez-Peinado, A.J.; Martin-Aranda, R.M. Fenton-like oxidation of Orange II solutions using heterogeneous catalysts based on saponite clay. Appl. Catal. B: Environ. 2007, 71, 44-56. [CrossRef]

18. Hassan, H.; Hameed, B.H. Iron-clay as effective heterogeneous Fenton catalyst for the decolorization of Reactive Blue 4. Chem. Eng. J. 2011, 171, 912-918. [CrossRef]

19. Duarte, F.; Maldonado-Hodar, F.J.; Perez-Cadenas, A.F.; Madeira, L.M. Fenton-like degradation of azo-dye Orange II catalyzed by transition metals on carbon aerogels. Appl. Catal. B: Environ. 2009, 85, 139-147. [CrossRef]

20. Wang, L.; Yao, Y.; Zhang, Z.; Sun, L.; Lu, W.; Chen, W.; Chen, H. Activated carbon fibers as an excellent partner of Fenton catalyst for dyes decolorization by combination of adsorption and oxidation. Chem. Eng. J. 2014, 251, 348-354. [CrossRef]

21. Carrasco-Diaz, M.R.; Castillejos-Lopez, E.; Cerpa-Naranjo, A.; Rojas-Cervantes, M.L. On the textural and crystalline properties of Fe-carbon xerogels. Application as Fenton-like catalysts in the oxidation of paracetamol by $\mathrm{H}_{2} \mathrm{O}_{2}$. Microporous Mesoporous Mater. 2017, 237, 282-293. [CrossRef]

22. Wang, Y.; Zhao, H.; Zhao, G. Iron-copper bimetallic nanoparticles embedded within ordered mesoporous carbon as effective and stable heterogeneous Fenton catalyst for the degradation of organic contaminants. Appl. Catal. B Environ. 2015, 164, 396-406. [CrossRef]

23. Gholami, P.; Dinpazhoh, L.; Khataee, A.; Hassani, A.; Bhatnagar, A. Facile hydrothermal synthesis of novel Fe-Cu layered double hydroxide/biochar nanocomposite with enhanced sonocatalytic activity for degradation of cefazolin sodium. J. Hazard. Mater. 2020, 381, 120742. [CrossRef]

24. Kolpin, D.W.; Furlong, E.T.; Meyer, M.T.; Thurman, E.M.; Zaugg, S.D.; Barber, L.B.; Buxton, H.T. Pharmaceuticals, Hormones, and Other Organic Wastewater Contaminants in U.S. Streams, 1999-2000: A National Reconnaissance. Environ. Sci. Technol. 2002, 36, 1202-1211. [CrossRef] [PubMed] 
25. Gomez, M.J.; Martinez Bueno, M.J.; Lacorte, S.; Fernandez-Alba, A.R.; Agueera, A. Pilot survey monitoring pharmaceuticals and related compounds in a sewage treatment plant located on the Mediterranean coast. Chemosphere 2007, 66, 993-1002. [CrossRef] [PubMed]

26. Serp, P.; Castillejos, E. Catalysis in Carbon Nanotubes. ChemCatChem 2010, 2, 41-47. [CrossRef]

27. Melchionna, M.; Marchesan, S.; Prato, M.; Fornasiero, P. Carbon nanotubes and catalysis: The many facets of a successful marriage. Catal. Sci. Technol. 2015, 5, 3859-3875. [CrossRef]

28. Tian, X.; Liu, Y.; Chi, W.; Wang, Y.; Yue, X.; Huang, Q.; Yu, C. Catalytic Degradation of Phenol and p-Nitrophenol Using $\mathrm{Fe}_{3} \mathrm{O}_{4} / \mathrm{MWCNT}$ Nanocomposites as Heterogeneous Fenton-Like Catalyst. Water Air Soil Pollut. 2017, 228, 1-12. [CrossRef]

29. Liao, Q.; Sun, J.; Gao, L. Degradation of phenol by heterogeneous Fenton reaction using multi-walled carbon nanotube supported $\mathrm{Fe}_{2} \mathrm{O}_{3}$ catalysts. Colloids Surf. A Physicochem. Eng. Asp. 2009, 345, 95-100. [CrossRef]

30. Zhou, L.; Zhang, H.; Ji, L.; Shao, Y.; Li, Y. $\mathrm{Fe}_{3} \mathrm{O}_{4} / \mathrm{MWCNT}$ as a heterogeneous Fenton catalyst: Degradation pathways of tetrabromobisphenol A. RSC Adv. 2014, 4, 24900-24908. [CrossRef]

31. Cleveland, V.; Bingham, J.-P.; Kan, E. Heterogeneous Fenton degradation of bisphenol A by carbon nanotube-supported $\mathrm{Fe}_{3} \mathrm{O}_{4}$. Sep. Purif. Technol. 2014, 133, 388-395. [CrossRef]

32. Yu, L.; Yang, X.; Ye, Y.; Wang, D. Efficient removal of atrazine in water with a $\mathrm{Fe}_{3} \mathrm{O}_{4} / \mathrm{MWCNTs}$ nanocomposite as a heterogeneous Fenton-like catalyst. RSC Adv. 2015, 5, 46059-46066. [CrossRef]

33. Tang, J.; Wang, J. Fe3O4-MWCNT Magnetic Nanocomposites as Efficient Fenton-Like Catalysts for Degradation of Sulfamethazine in Aqueous Solution. Chem. Sel. 2017, 2, 10727-10735.

34. Deng, J.; Wen, X.; Li, J. Degradation of methylene blue by heterogeneous Fenton-like reaction using Fe3O4/carbon nanotube composites. Acta Sci. Circumstantiae 2014, 34, 1436-1442.

35. Zhang, L.; Nie, Y.; Hu, C.; Qu, J. Enhanced Fenton degradation of Rhodamine B over nanoscaled Cu-doped $\mathrm{LaTiO}_{3}$ perovskite. Appl. Catal. B Environ. 2012, 125, 418-424. [CrossRef]

36. Delgado-Gomez, F.J.; Calvino-Casilda, V.; Cerpa-Naranjo, A.; Rojas-Cervantes, M.L. Alkaline-doped multiwall carbon nanotubes as efficient catalysts for the Knoevenagel condensation. Mol. Catal. 2017, 443, 101-109. [CrossRef]

37. Sendel, E.B. Colorimetric Determination of Trases of Metals; IntersciencePublishers, Inc.: Hoboken, NJ, USA, 1959.

38. Velichkova, F.; Julcour-Lebigue, C.; Koumanova, B.; Delmas, H. Heterogeneous Fenton oxidation of paracetamol using iron oxide (nano)particles. J. Environ. Chem. Eng. 2013, 1, 1214-1222. [CrossRef]

39. Franz, M.; Arafat, H.A.; Pinto, N.G. Effect of chemical surface heterogeneity on the adsorption mechanism of dissolved aromatics on activated carbon. Carbon 2000, 38, 1807-1819. [CrossRef]

40. Kong, S.-H.; Watts, R.J.; Choi, J.-H. Treatment of petroleum-contaminated soils using iron-mineral-catalyzed hydrogen peroxide. Chemosphere 1998, 37, 1473-1482. [CrossRef]

41. Huang, H.H.; Lu, M.C.; Chen, J.N. Catalytic Decomposition of Hydrogen Peroxide and 2-chlorophenol with iron oxides. Water Res. 2001, 35, 2291-2299. [CrossRef]

42. Li, K.; Zhao, Y.; Janik, M.J.; Song, C.; Guo, X. Magnetic mesoporous Fe3O4/C/Cu composite as Fenton-like catalysts. Appl. Surf. Sci. 2017, 396, 1383-1392. [CrossRef]

43. Costa, R.C.C.; Lelis, M.d.F.F.; Oliveira, L.C.A.; Fabris, J.D.; Ardisson, J.D.; Rios, R.R.V.A.; Silva, C.N.; Lago, R.M. Remarkable effect of $\mathrm{Co}$ and $\mathrm{Mn}$ on the activity of $\mathrm{Fe}_{3-\mathrm{x}} \mathrm{M}_{\mathrm{x}} \mathrm{O}_{4}$ promoted oxidation of organic contaminants in aqueous medium with $\mathrm{H}_{2} \mathrm{O}_{2}$. Catal. Commun. 2003, 4, 525-529. [CrossRef]

44. Deng, J.; Jiang, J.; Zhang, Y.; Lin, X.; Du, C.; Xiong, Y. FeVO4 as a highly active heterogeneous Fenton-like catalyst towards the degradation of Orange II. Appl. Catal. B Environ. 2008, 84, 468-473. [CrossRef]

45. Sires, I.; Garrido, J.A.; Rodriguez, R.M.; Cabot, P.1.1.; Centellas, F.; Arias, C.; Brillas, E. Electrochemical Degradation of Paracetamol from Water by Catalytic Action of $\mathrm{Fe}^{2+}, \mathrm{Cu}^{2+}$, and UVA Light on Electrogenerated Hydrogen Peroxide. J. Electrochem. Soc. 2006, 153, D1-D9. [CrossRef]

46. Yang, L.; Yu, L.E.; Ray, M.B. Degradation of paracetamol in aqueous solutions by $\mathrm{TiO}_{2}$ photocatalysis. Water Res. 2008, 42, 3480-3488. [CrossRef]

47. Pereira, M.F.R.; Soares, S.F.; Orfao, J.J.M.; Figueiredo, J.L. Adsorption of dyes on activated carbons: Influence of surface chemical groups. Carbon 2003, 41, 811-821. [CrossRef]

(C) 2020 by the authors. Licensee MDPI, Basel, Switzerland. This article is an open access article distributed under the terms and conditions of the Creative Commons Attribution (CC BY) license (http://creativecommons.org/licenses/by/4.0/). 